\title{
Summary of Ground-Water Data for Tutuila and Aunuu, American Samoa, for October 1987 Through September 1997
}

U.S. GEOLOGICAL SURVEY

Open-File Report 99-252



Prepared in cooperation with the AMERICAN SAMOA ENVIRONMENTAL PROTECTION AGENCY 


\section{Summary of Ground-Water Data for Tutuila and Aunuu, American Samoa, for October 1987 Through September 1997}

By Scot K. Izuka

U.S. GEOLOGICAL SURVEY

Open-File Report 99-252

Prepared in cooperation with the

AMERICAN SAMOA ENVIRONMENTAL PROTECTION AGENCY 


\section{U.S. DEPARTMENT OF THE INTERIOR BRUCE BABBITT, Secretary}

U.S. GEOLOGICAL SURVEY

Charles G. Groat, Director

The use of firm, trade, and brand names in this report is for identification purposes only and does not constitute endorsement by the U.S. Geological Survey.

For additional information write to:

Copies of this report can be purchased from:

District Chief

U.S. Geological Survey

677 Ala Moana Blvd., Suite 415

Honolulu, HI 96813
U.S. Geological Survey

Branch of Information Services

Box 25286

Denver, CO 80225-0286 


\section{CONTENTS}

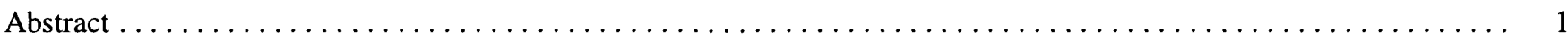

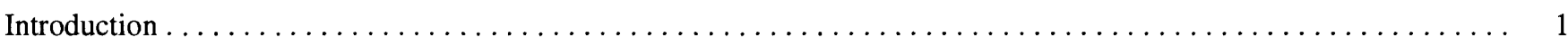

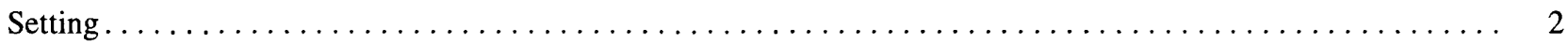

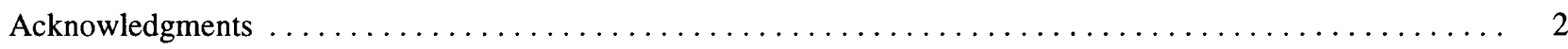





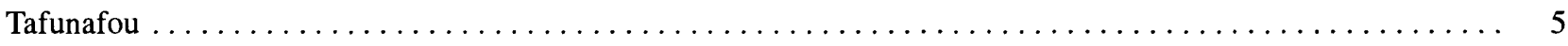

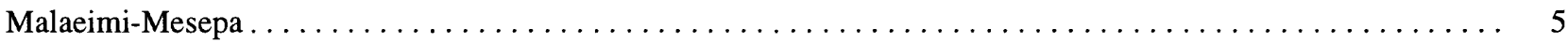





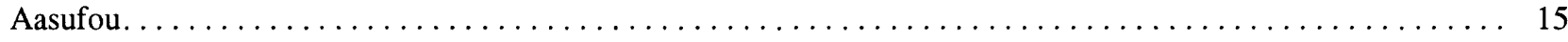

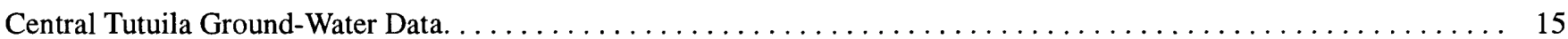

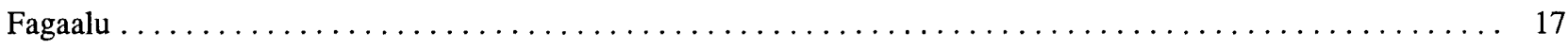

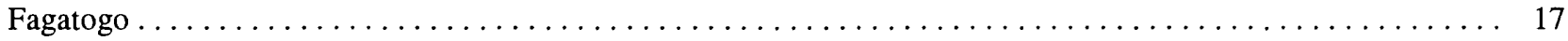

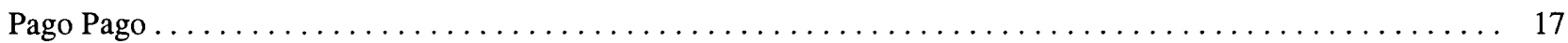

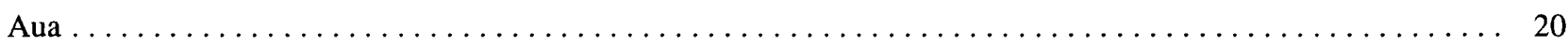



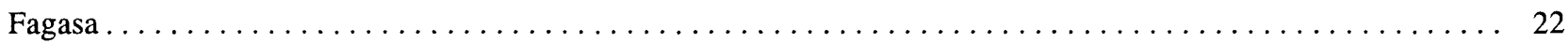



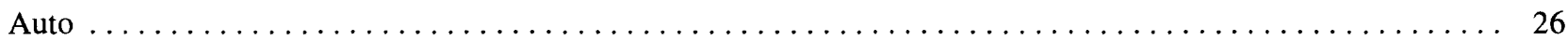

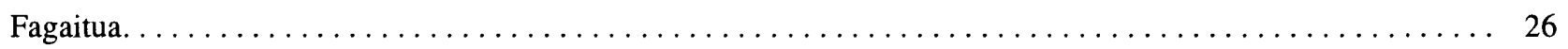

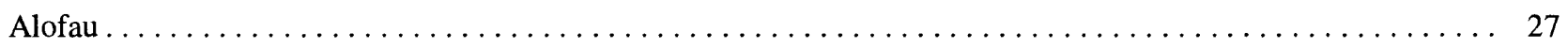

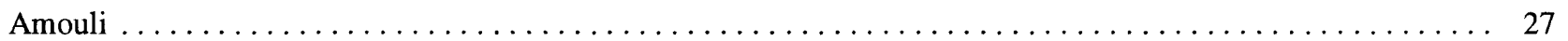

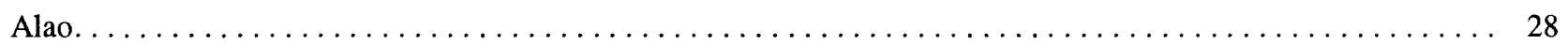

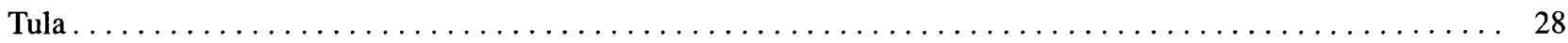

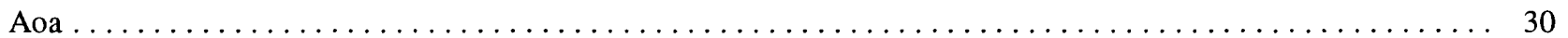

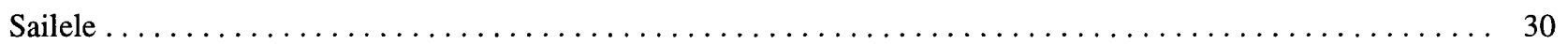

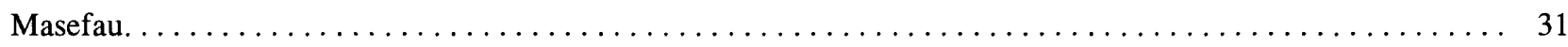

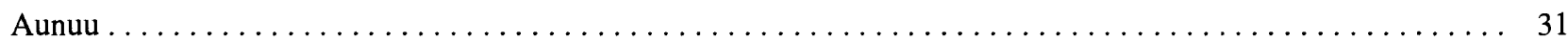

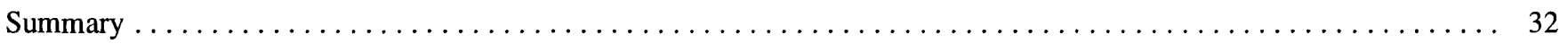

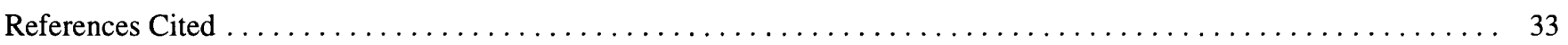

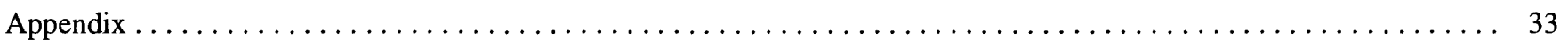

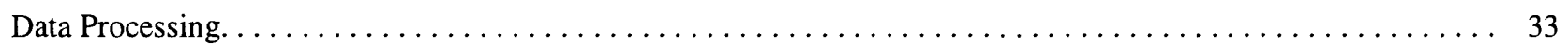




\section{FIGURES}

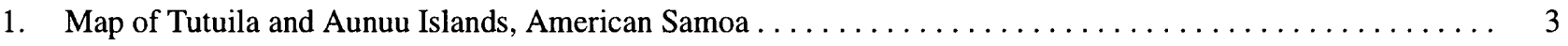

2. Graphs showing monthly rainfall recorded at the Aasufou and Afono rain gages, Tutuila, American Samoa ... 4

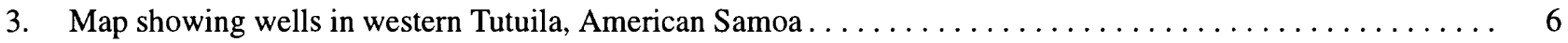

4-12. Graphs showing:

4. Ground-water pumpage and chloride concentrations in Tafunafou, Tutuila, American Samoa. ........ 7

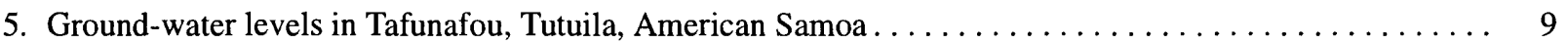

6. Ground-water pumpage and chloride concentrations in the Malaeimi-Mesepa area, Tutuila, American Samoa. ................................... 10

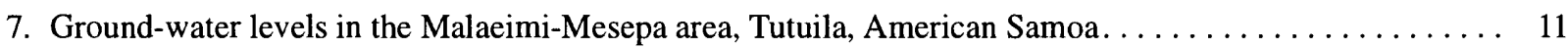

8. Ground-water pumpage and chloride concentrations in Iliili, Tutuila, American Samoa . . . . . . . . 12

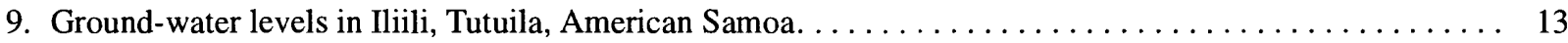

10. Ground-water pumpage and chloride concentrations in the Malaeloa-Leone area, Tutuila, American Samoa $\quad 13$



12. Ground-water pumpage and chloride concentrations in Aasufou, Tutuila, American Samoa......... 15

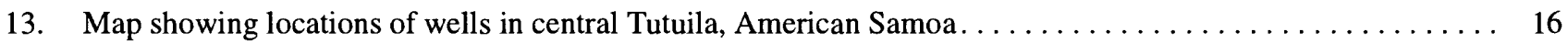

14-25. Graphs showing:

14. Ground-water pumpage and chloride concentrations in Fagaalu, Tutuila, American Samoa ........ 18

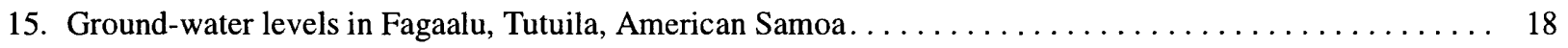

16. Ground-water pumpage and chloride concentrations in Fagatogo, Tutuila, American Samoa. . . . . . . . 18

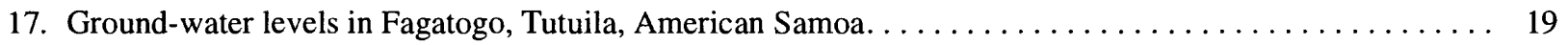

18. Ground-water pumpage and chloride concentrations in Pago Pago, Tutuila, American Samoa......... . 19

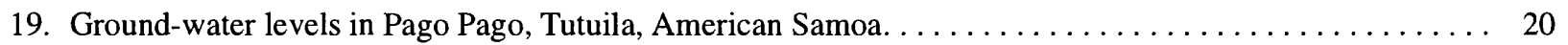

20. Ground-water pumpage and chloride concentrations in Aua, Tutuila, American Samoa ......... 21

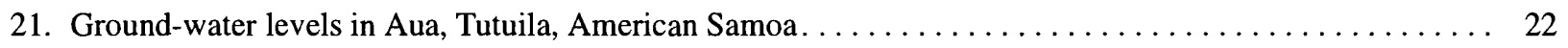

22. Ground-water pumpage and chloride concentrations in Laulii, Tutuila, American Samoa . . . . . . . . 23

23. Ground-water levels in Laulii, Tutuila, American Samoa $\ldots \ldots \ldots \ldots \ldots \ldots \ldots \ldots \ldots \ldots \ldots \ldots$

24. Ground-water pumpage and chloride concentrations in Fagasa, Tutuila, American Samoa .......... 24

25. Map showing wells in eastern Tutuila and Aunuu, American Samoa $\ldots \ldots \ldots \ldots \ldots \ldots \ldots \ldots \ldots \ldots$

26-35. Graphs showing:

26. Ground-water pumpage and chloride concentrations in Auto, Tutuila, American Samoa.......... 26

27. Ground-water pumpage and chloride concentrations in Fagaitua, Tutuila, American Samoa ......... 26

28. Ground-water pumpage and chloride concentrations in Alofau, Tutuila, American Samoa . . . . . . . . . 27

29. Ground-water levels in Amouli, Tutuila, American Samoa ........................ 27

30. Ground-water pumpage and chloride concentrations in Alao, Tutuila, American Samoa .......... 28

31. Ground-water pumpage and chloride concentrations in Tula, Tutuila, American Samoa ........... 29

32. Ground-water pumpage and chloride concentrations in Aoa, Tutuila, American Samoa ......... 30

33. Ground-water pumpage and chloride concentrations in Sailele, Tutuila, American Samoa ......... 31

34. Ground-water pumpage and chloride concentrations in Masefau, Tutuila, American Samoa .......... 31

35. Ground-water pumpage and chloride concentrations on Aunuu, American Samoa. . . . . . . . . . . 32 


\begin{tabular}{rll}
\hline Multiply & by & to obtain \\
\hline inch (in.) & 2.54 & centimeters \\
foot (ft) & 0.3048 & meter \\
mile, statute (mi) & 1.609 & kilometers \\
square mile $\left(\mathrm{mi}^{2}\right)$ & 2.590 & square kilometers \\
gallons per day $(\mathrm{gal} / \mathrm{d})$ & 3.785 & liters per day \\
million gallons per day (Mgal/d) & 0.04381 & cubic meter per second \\
\hline
\end{tabular}

Abbreviations used in water-quality descriptions

$$
\mathrm{mg} / \mathrm{L}=\text { milligrams per liter }
$$

\section{Vertical datum}

All elevations in this report are referenced relative to mean sea level. 


\title{
Summary of Ground-Water Data for Tutuila and Aunuu, American Samoa, for October 1987 Through September 1997
}

\author{
By Scot K. Izuka
}

\section{Abstract}

Ground-water and rainfall data for the period October 1987 through September 1997 from Tutuila and Aunuu, American Samoa, are plotted in time-series graphs and summarized. The data include pumpage and chloride concentrations from 53 production wells on Tutuila, including 5 new wells that were put into production between October 1996 and September 1997, 3 production wells on Aunuu, water-level measurements from 16 wells on Tutuila, and rainfall data from 2 gages on Tutuila.

Mean annual rainfall was 164 inches at the gage in Afono and 210 inches at the gage in Aasufou during the period October 1987 through September 1997. Rainfall in the 12-month period from October 1996 through September 1997 totaled 210 inches at the Afono gage and 234 inches at the Aasufou gage.

In the Tafuna-Leone Plain, most wells were pumped at rates from 0.2 to 0.5 million gallons per day and had chloride concentrations usually less than 500 milligrams per liter. In the 12-month period ending September 1997, the combined pumpage from wells in the Tafuna-Leone Plain was about 6.3 million gallons per day and the chloride concentrations in most wells remained below 200 milligrams per liter. In Aasufou, wells produced 0.04 to 0.05 million gallons per day and chloride concentrations remained near 15 milligrams per liter.
Most wells in central and eastern Tutuila were pumped at rates less than 0.1 million gallons per day. Wells in the Fagatogo, Pago Pago, and Aua areas, which averaged more than 0.4 million gallons per day of pumpage, are exceptions. Some wells in central and eastern Tutuila had chloride concentrations that frequently exceeded 500 milligrams per liter. In the 12-month period ending September 1997, chloride concentrations in the production wells in Aua rose to the highest levels on record. In the 12-month period ending September 1997, water levels in Tafunafou, Iliili, Pago Pago, and Laulii remained at about the same elevation above mean sea level as in previous years, water levels in Aua remained below mean sea level as in previous years, and water levels in Malaeimi and Fagaalu declined relative to previous years.

The three production wells on Aunuu have been pumped at various rates less than 0.1 million gallons per day and had chloride concentrations usually in excess of 500 and often in excess of 1,000 milligrams per liter.

\section{INTRODUCTION}

The American Samoa Government, through the American Samoa Environmental Protection Agency (ASEPA), American Samoa Power Authority (ASPA), and the Department of Public Works (DPW), has maintained a cooperative effort with the U.S. Geological Survey (USGS) to collect the principal data needed to monitor ground-water resources on Tutuila, the largest and most populated island in the South Pacific 
archipelago of American Samoa, and the small, nearby island of Aunuu (fig. 1). For convenience of discussion, the wells on Tutuila are grouped into three regions, western, eastern and central, as shown in figure 1 . The data are discussed by area (groups of closely spaced wells) within each of the regions. Following the wellnaming convention used by ASPA, the areas in this report bear the name of the nearest village.

This report summarizes pumpage and chlorideconcentration data from 53 wells on Tutuila and 3 wells on Aunuu that were in production during the period October 1987 through September 1997. Although some of these wells have not been pumped in recent years, they are included in this report for historical purposes. The concentration of chloride ions is an indicator of the salinity of ground water pumped from wells; salinity is a principal factor limiting the availability of ground water on oceanic islands.

The report also summarizes water levels monitored in the period from October 1987 through September 1997 at 15 non-pumping wells and 1 pumping well on Tutuila. Rainfall data from the same period from two gages are summarized in this report to allow comparisons with the ground-water data.

This report is the third in a series of ground-water data summaries (Izuka, 1996, 1997). The purpose of these reports is to present the data in time-series graphs to facilitate analysis of trends. Each successive report in the series updates the previous report by adding the next 12 months of data. The discussion of the data for most areas is presented in two parts consisting of: (1) a general description of the well field and long-term history, and (2) a section highlighting trends in the most recent 12 months and comparing them to trends in the previous years (except when an area either has no data in the most recent 12-month period, or has data only from the most recent 12-month period).

\section{Setting}

Tutuila is a volcanic island of about $53 \mathrm{mi}^{2}$ in the tropical South Pacific (fig. 1). The island is narrow and elongate in the east-west direction and characterized mostly by steep, deeply eroded mountains that rise abruptly from the ocean to elevations as high as 2,140 $\mathrm{ft}$. The exception to this general topography is the relatively flat Tafuna-Leone Plain in the southwest which extends from Tafunafou to Leone. The mountainous part of Tutuila is composed of Pliocene- to Pleistoceneage shield-volcano alkalic basalts, andesites, and trachytes that have relatively low permeabilities (Stearns, 1944; Macdonald, 1944, 1968; Davis, 1963; Bentley, 1975). The Tafuna-Leone Plain is composed of younger (Holocene age), more permeable lava flows and pyroclastic cones (Stearns, 1944; Davis, 1963; Bentley, 1975). Ground-water production is high on the TafunaLeone Plain. Elsewhere on Tutuila, wells are located in small valleys or low-lying areas near the coast. Wells drilled on the top of Olotele Mountain near Aasufou are the only exception.

The small island of Aunuu $\left(0.6 \mathrm{mi}^{2}\right)$, less than $1 \mathrm{mi}$ off the southeastern shore of Tutuila, is a tuff (consolidated volcanic ash) cone with a coastal plain on its western side. The coastal plain is about $2,000 \mathrm{ft}$ wide in the east-west direction and 4,000 ft long in the northsouth direction and is composed of partly consolidated marine and terrigenous sediment. Two marshes are present on Aunuu: one in the center of the tuff cone and the other at the inland edge of the coastal plain where it abuts the slope of the tuff cone. All of the ground-water production on Aunuu comes from wells in the coastal plain sediments.

\section{Acknowledgments}

This report was produced under a cooperative agreement with the ASEPA. Data were collected by the ASPA. The author gratefully acknowledges Togipa Tausaga (Director, ASEPA), Abe Malae (Director, ASPA), Sheila Wiegman (ASEPA), and Wilfredo Carreon (ASPA) for their assistance.

\section{RAINFALL}

Mean annual rainfall at the gage in Afono near Pioa Mountain was 164 in. and 210 in. at the rain gage in Aasufou (fig. 1), during the period October 1987 through September 1997. Plots of mean monthly rainfall show a seasonal pattern with a wet season from October through April and a dry season from May to September (fig. 2). The seasonal pattern is also apparent in the 3-month backward-looking moving average in the period between 1987 and 1992, but is obscured in the relatively high rainfall period between late 1994 through 1995. 


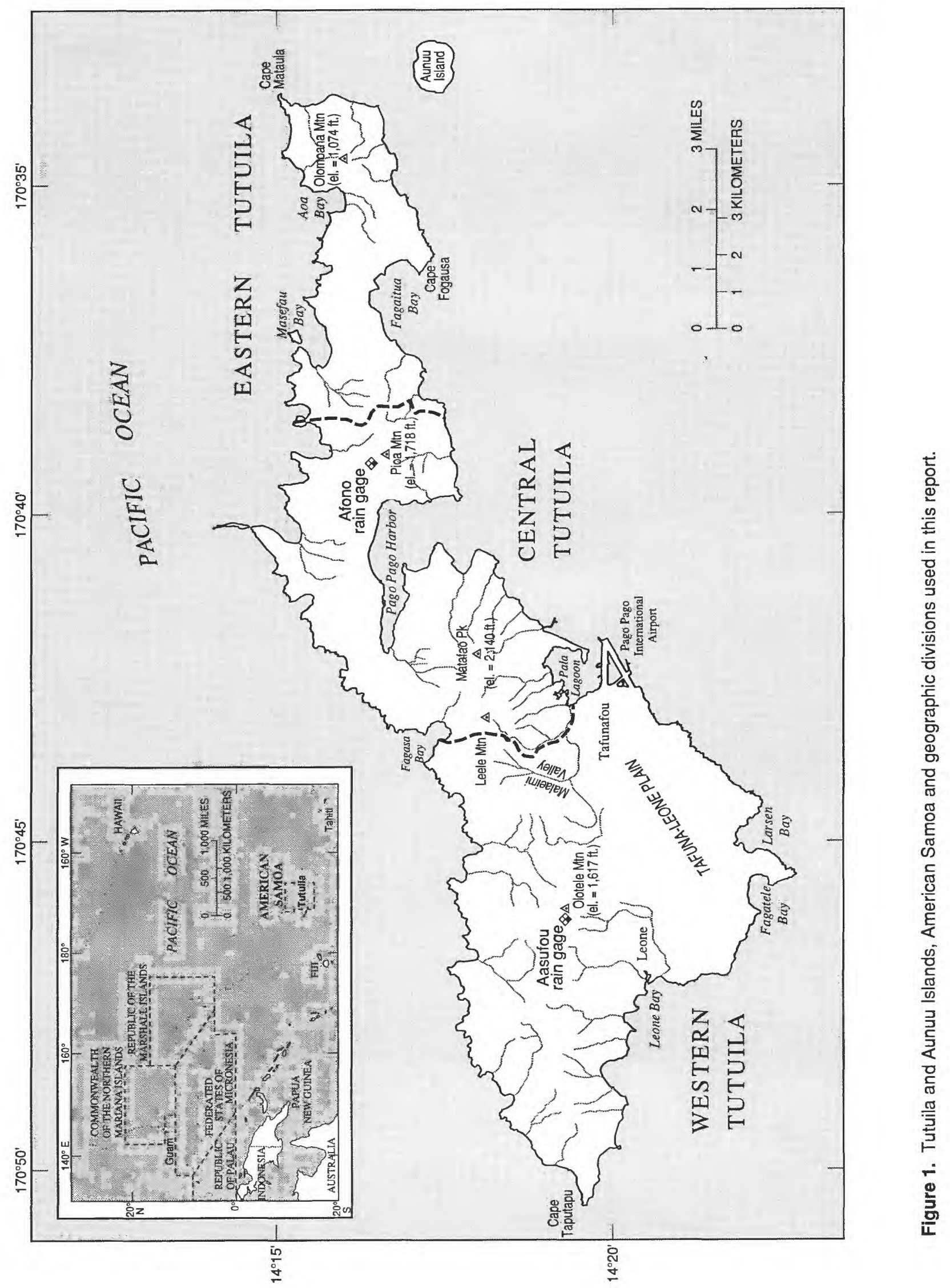



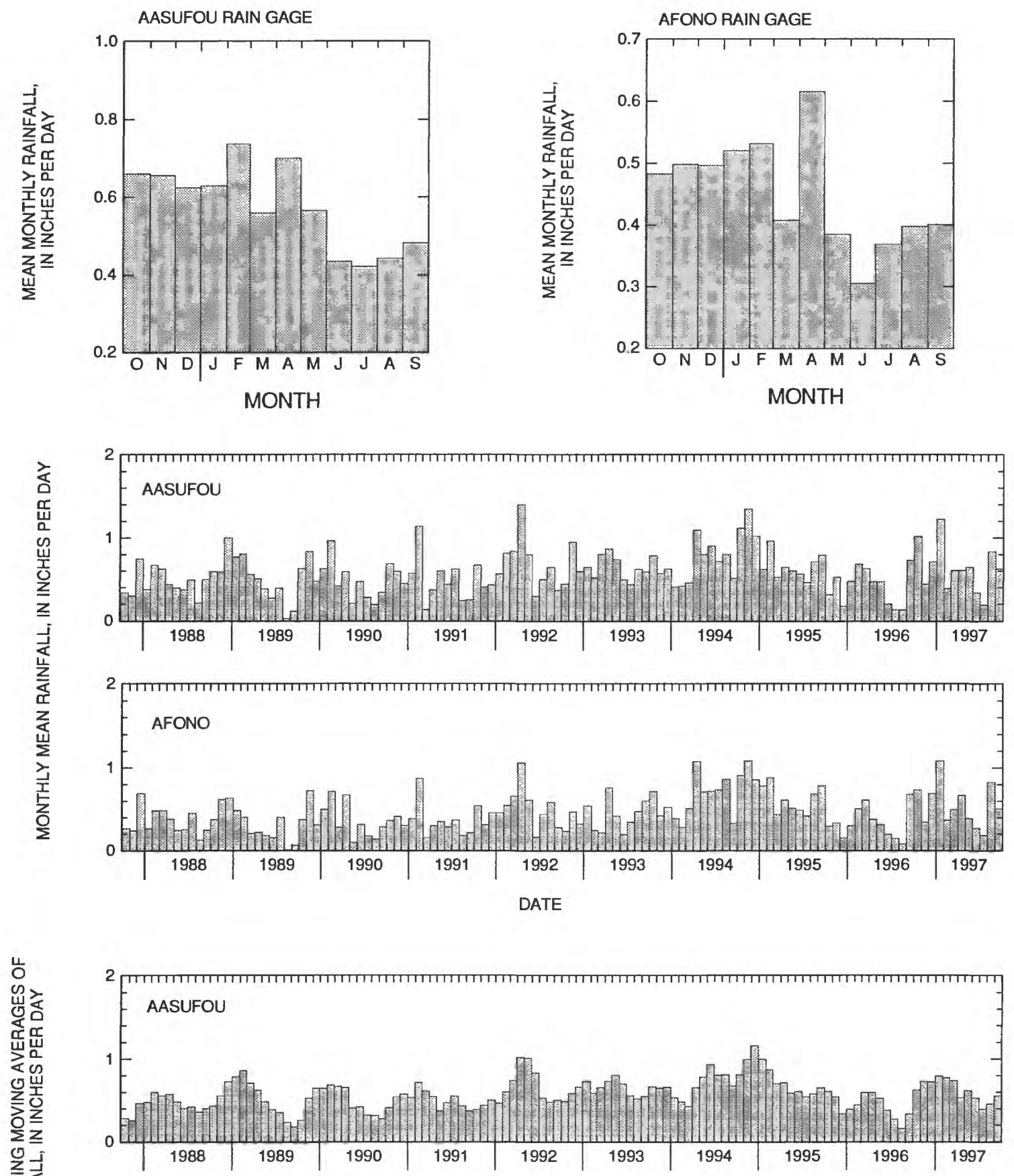
Trends during the 12-month period ending September 1997.--Rainfall in the 12-month period from October 1996 through September 1997 totaled 210 in. at the Afono gage, and 234 in. at the Aasufou gage. Both of these totals are higher than the mean annual rainfall for the 10-year period October 1987 through September 1997.

\section{WESTERN TUTUILA GROUND-WATER DATA}

Western Tutuila is the site of the most productive wells on Tutuila, including the those on the TafunaLeone Plain, which include wells in Tafunafou, Malaeimi, Mesepa, Iliili, and Malaeloa (fig. 3). Also included in western Tutuila are the wells in Aasufou near the summit of Olotele Mountain (in previous reports of this series [Izuka, 1996, 1997], this area was referred to as Aoloaufou based on the 1:24,000-scale topographic map by the USGS [1989], but in this report the area is referred to as Aasufou, which is how it is referred to by ASPA).

\section{Tafunafou}

The wells in Tafunafou (fig. 3) are among the most productive on Tutuila. The wells are densely clustered in the village of Tafunafou and each has produced about 0.2 to $0.5 \mathrm{Mgal} / \mathrm{d}$ over various periods (fig. 4). Most wells show long periods of relatively steady pumping rates interrupted occasionally by periods of low or no pumpage (on the pumpage graphs, a wide bar that is much lower than the adjacent bars may indicate that non-pumping periods are included in that interval [see appendix]); two wells (61 and 81) have been pumped continuously at nearly the same rate for the entire 10year period shown in figure 4 . Chloride concentrations at Tafunafou wells have varied over a large range from 15 to more than $1,500 \mathrm{mg} / \mathrm{L}$, but, with the exception of wells 53 and 77, Tafunafou wells have produced water with chloride concentrations mostly below $500 \mathrm{mg} / \mathrm{L}$.

The time-series graphs of chloride concentration show a sawtooth pattern, with gradual rises during dry periods and sharp drops during rainy periods (figs. 2 and 4 ). Water levels in non-pumping monitor wells in Tafunafou varied mostly within 1 or $2 \mathrm{ft}$ of mean sea level (fig. 5).
Trends during the 12-month period ending September 1997.-- Only wells $33,60,61,72$, and 81 had reported pumpages in the 12-month period ending September 1997. Pumpage at well 33 continued in an irregular pattern as it had since 1991. Pumpage at well 60 was about $0.4 \mathrm{Mgal} / \mathrm{d}$, a rate at which the well had been pumped since early 1996 . Well 60 was pumped at about $0.4 \mathrm{Mgal} / \mathrm{d}$ as it had been since early 1996 , and well 72 was pumped at about $0.5 \mathrm{Mgal} / \mathrm{d}$ as it had been since 1995. Pumpage at wells 61 and 81 remained about the same as in the previous 9 years (fig. 4). The total production from wells in Tafunafou averaged $1.6 \mathrm{Mgal} / \mathrm{d}$ over the 12-month period.

Prior to October 1996, all Tafunafou wells for which data are available had shown increases in chloride concentrations, but chloride concentrations decreased during the 12-month period since October 1996. Water levels at monitor wells 1, 2, and 5 have continued the long-term trend, varying within 1 or $2 \mathrm{ft}$ of mean sea level through most of this period (fig. 5).

\section{Malaeimi-Mesepa}

Wells $67,69,88$, and 89 are in Malaeimi Valley, and well 85 is in Mesepa (fig. 3). Well 67 has pumped an average of $0.3 \mathrm{Mgal} / \mathrm{d}$ over the period shown in figure 6 . Well 85 was pumping at about $0.3 \mathrm{Mgal} / \mathrm{d}$ in 1984 , but pumpage was increased to about $0.5 \mathrm{Mgal} / \mathrm{d}$ in 1986 . Well 88 produced about 0.2 to $0.4 \mathrm{Mgal} / \mathrm{d}$ between 1991 and 1994, was not in operation for 2 years beginning late 1994, then resumed pumping at about 0.2 to $0.5 \mathrm{Mgal} / \mathrm{d}$ in late 1996 . Pumpage at well 89 began in 1985 at about 0.2 to $0.4 \mathrm{Mgal} / \mathrm{d}$ and increased to 0.5 $\mathrm{Mgal} / \mathrm{d}$ in late 1989. Chloride concentrations in water from these wells have remained below $60 \mathrm{mg} / \mathrm{L}$.

Well 69 began pumping in 1988 and produced about $0.01 \mathrm{Mgal} / \mathrm{d}$ until early 1990 , but chloride concentrations rose to more than $500 \mathrm{mg} / \mathrm{L}$ despite the low pumping rate (fig. 6); no pumpage has been reported from this well since 1990 .

Water-level monitoring began at well 88 in 1991, while it was still a production well. Water levels measured during pumping dropped as much as $72 \mathrm{ft}$ below mean sea level (fig. 7). The well stopped production in late 1994, at which time water levels began to rise as high as $90 \mathrm{ft}$ above mean sea level before pumping resumed again in late 1996. 


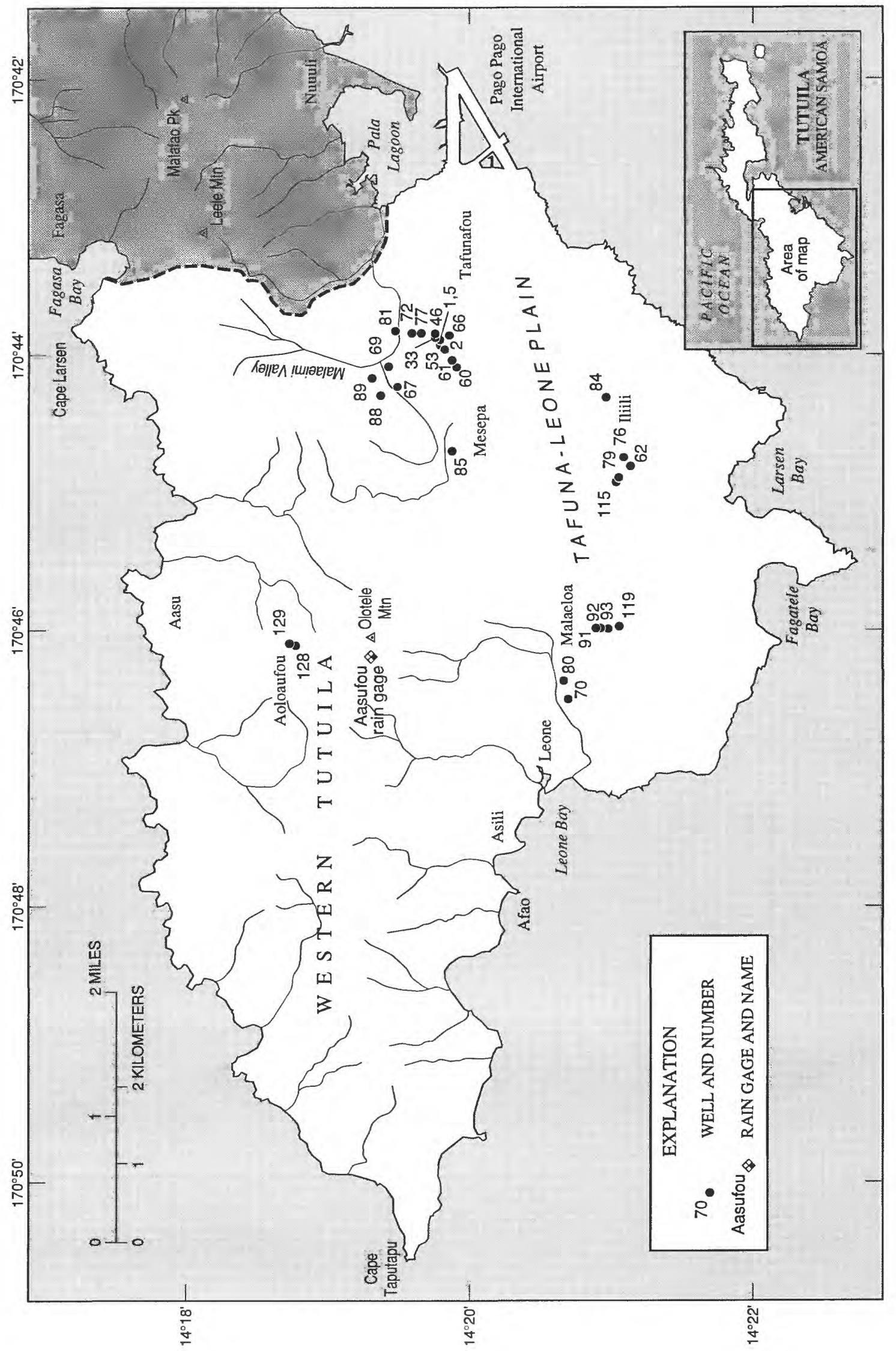

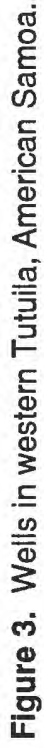


TAFUNAFOU 33

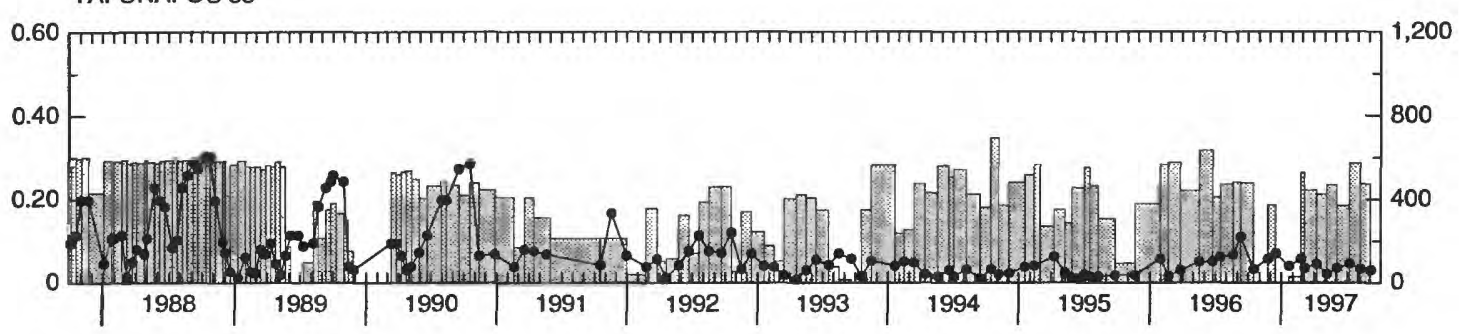

TAFUNAFOU 46



TAFUNAFOU 61

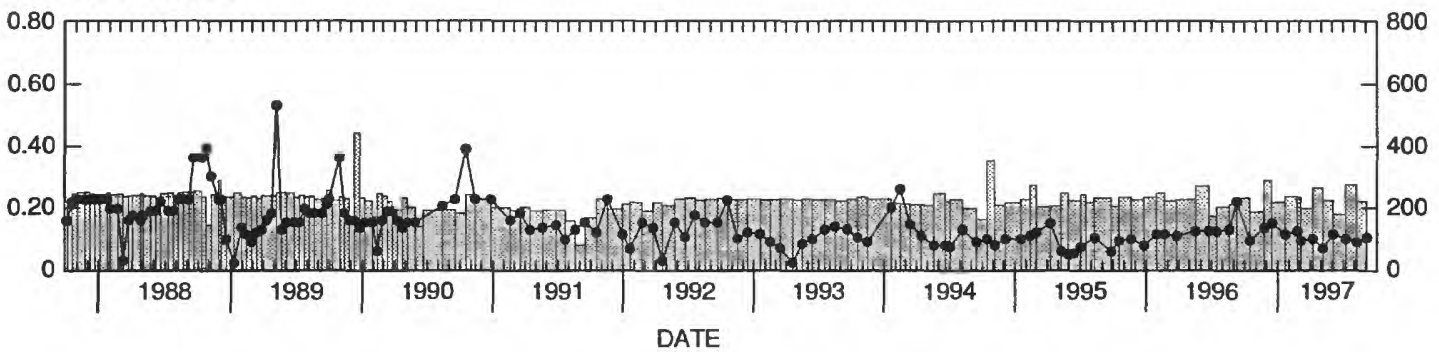

Figure 4. Ground-water pumpage and chloride concentrations in Tafunafou, Tutuila, American Samoa. (Connecting lines provided only as a visual aid and do not imply interpolation between data points. Connecting lines omitted where period between successive data points exceeds 6 months. Data from the American Samoa Power Authority.) 
TAFUNAFOU 66

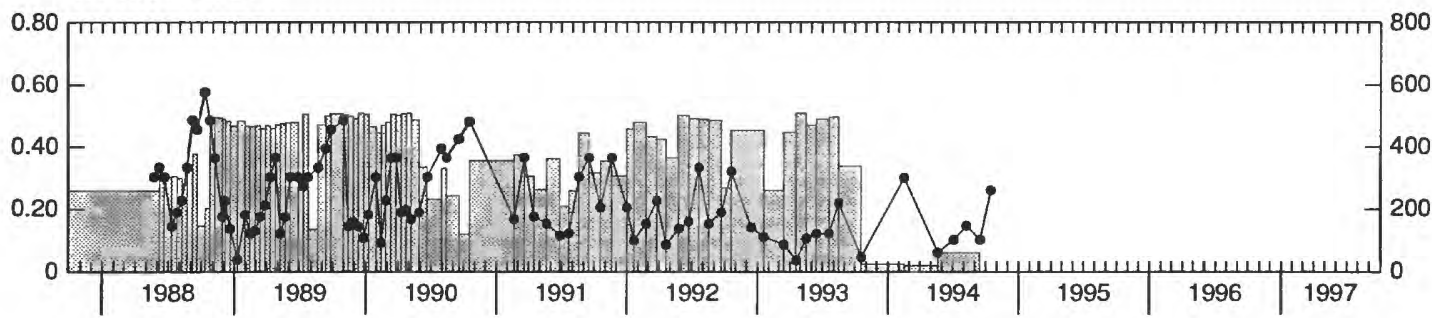

TAFUNAFOU 72

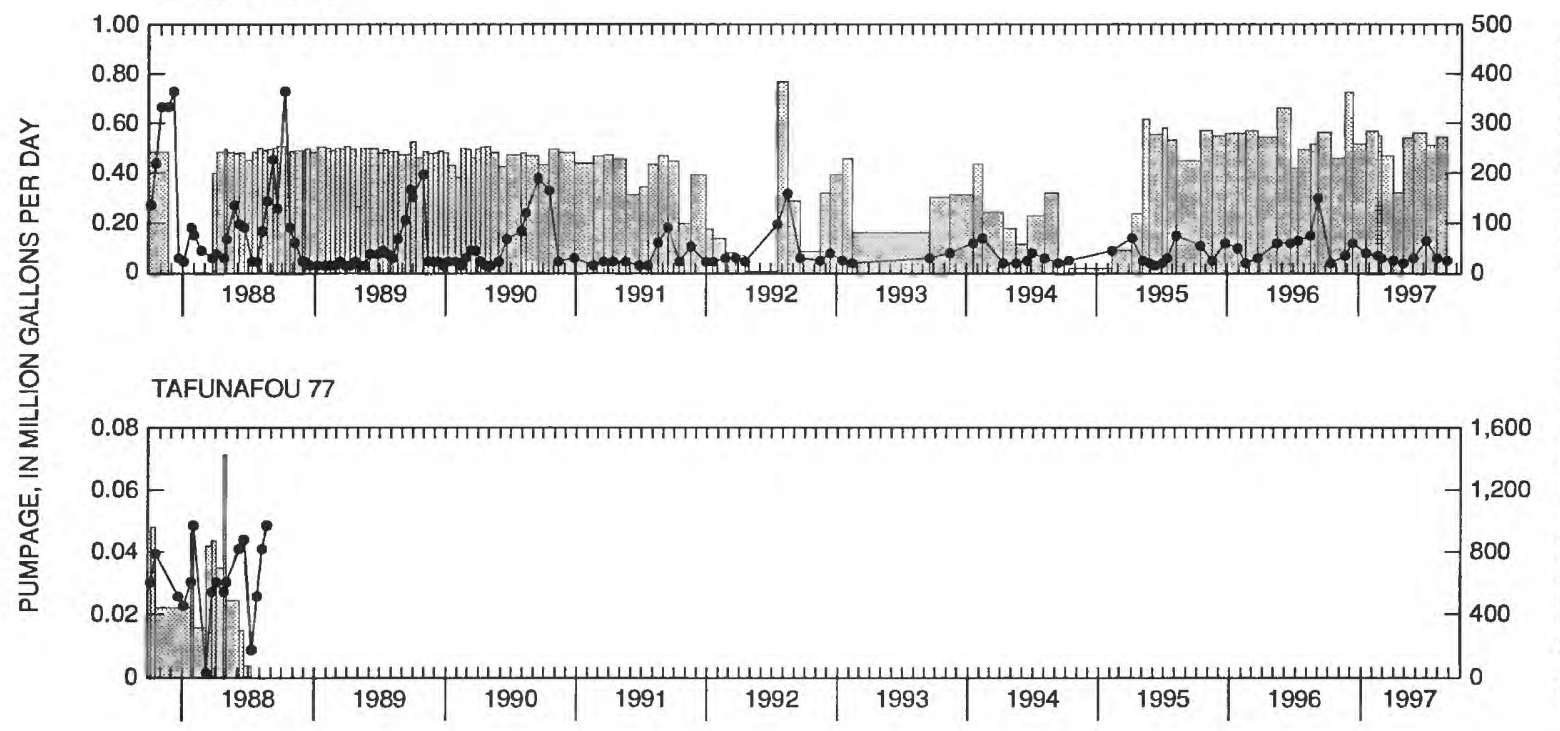

TAFUNAFOU 81

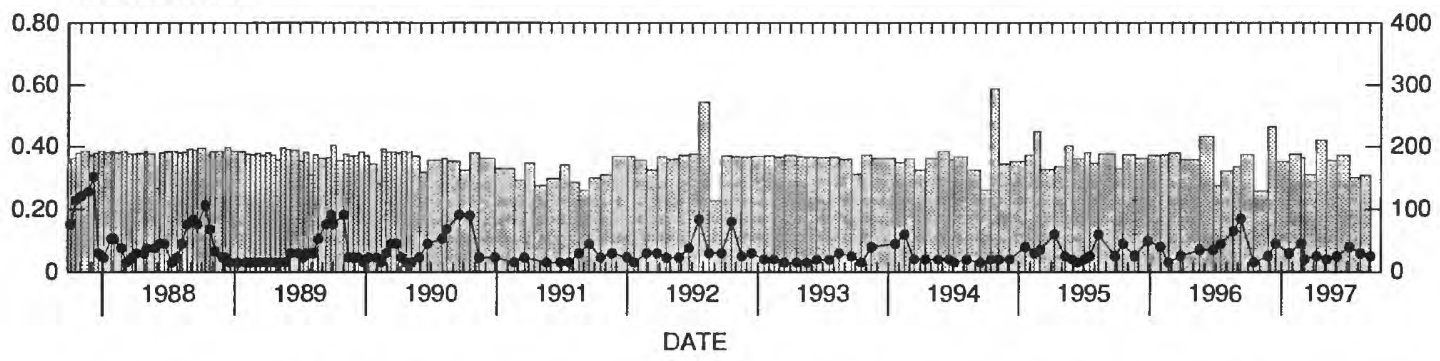

Figure 4. Ground-water pumpage and chloride concentrations in Tafunafou, Tutuila, American Samoa. (Connecting lines provided only as a visual aid and do not imply interpolation between data points. Connecting lines omitted where period between successive data points exceeds 6 months. Data from the American Samoa Power Authority.) --Continued. 


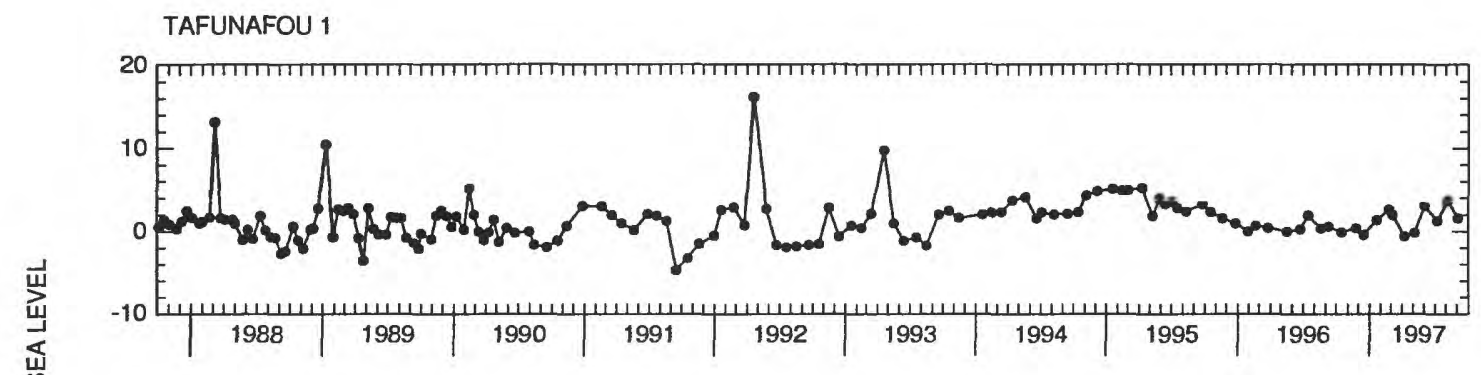

TAFUNAFOU 2

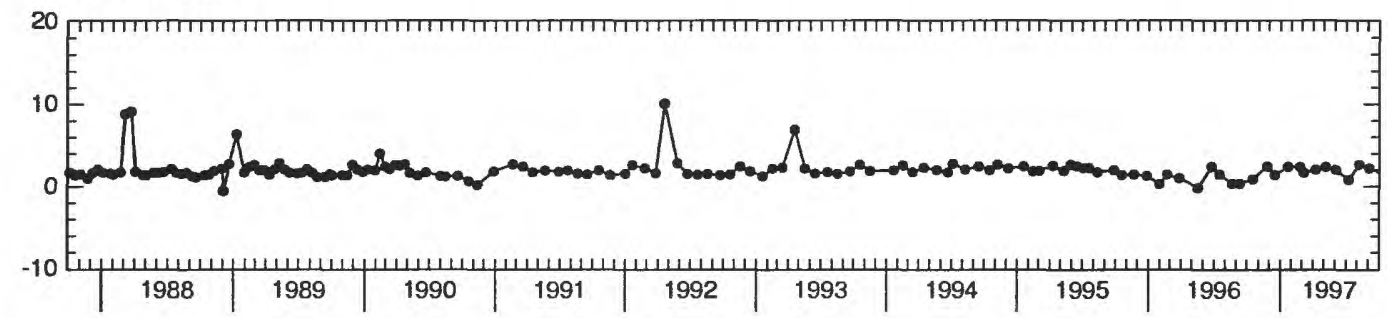

TAFUNAFOU 5

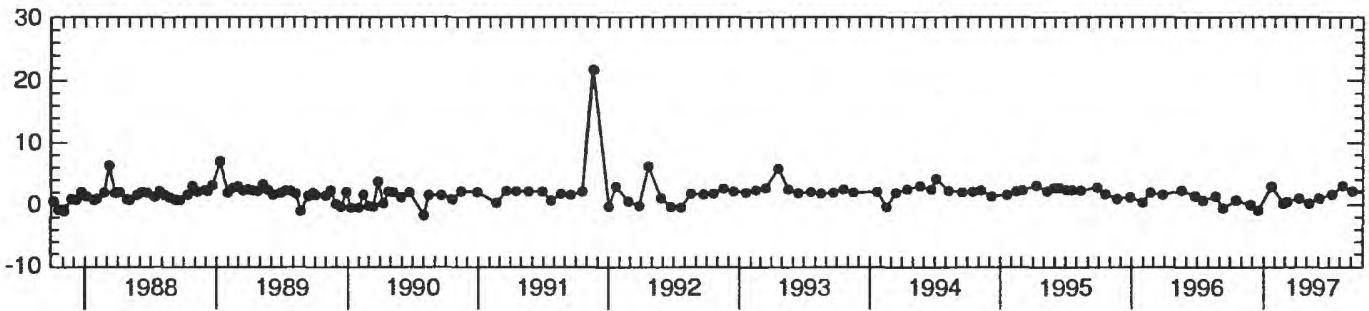

DATE

Figure 5. Ground-water levels in Tafunafou, Tutuila, American Samoa. (Connecting lines provided only as a visual aid and do not imply interpolation between data points. Data from the American Samoa Power Authority.) 
MALAEIMI 67

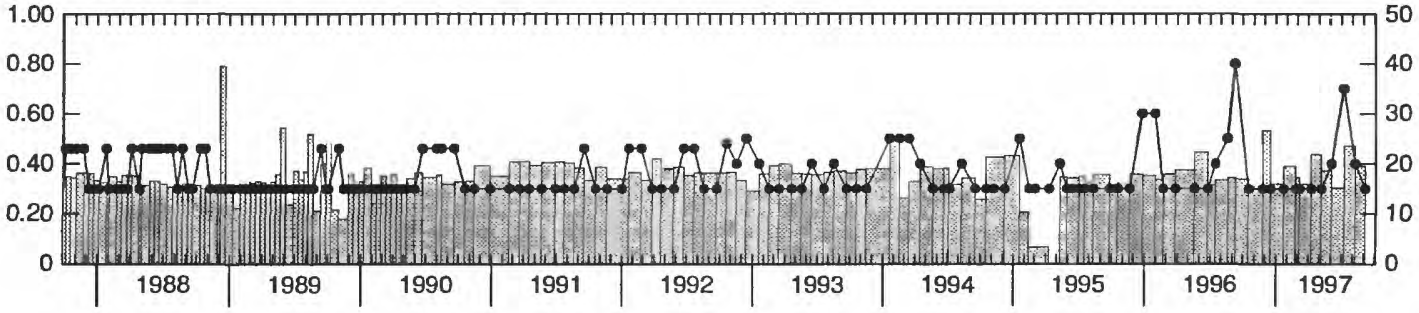

MALAEIMI 69



MALAEIMI 88

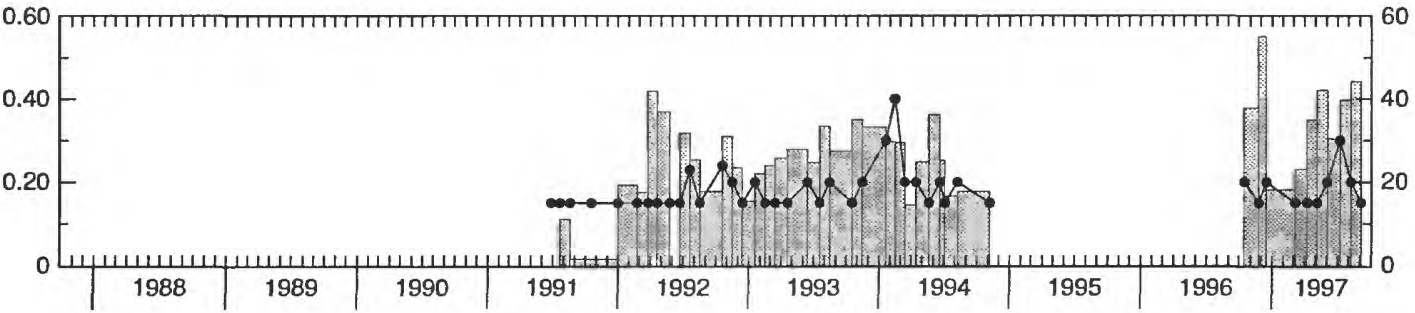

MALAEIMI 89

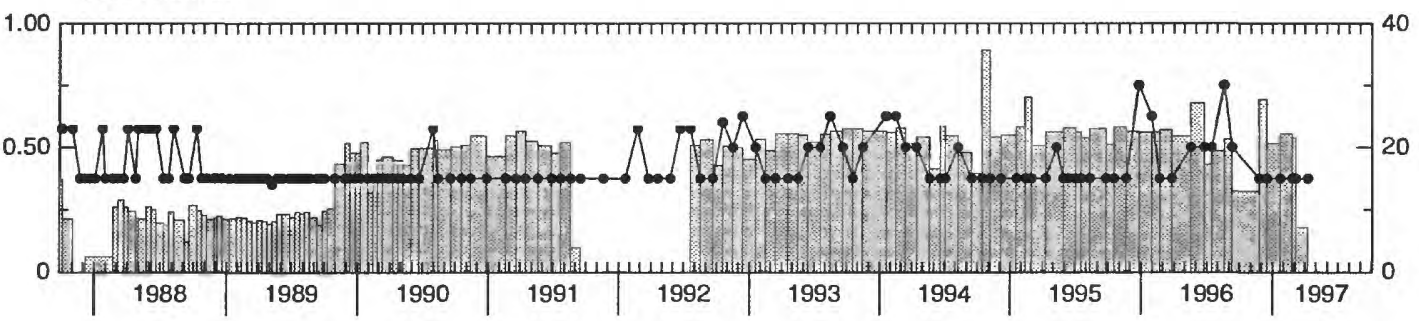

MESEPA 85

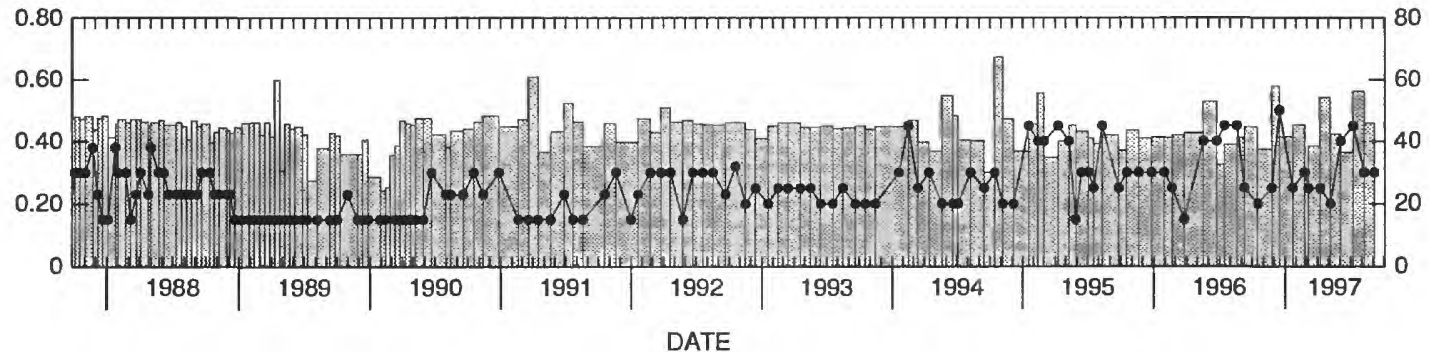

Figure 6. Ground-water pumpage and chloride concentrations in the Malaeimi-Mesepa area, Tutuila, American Samoa. (Connecting lines provided only as a visual aid and do not imply interpolation between data points. Data from the American Samoa Power Authority.) 


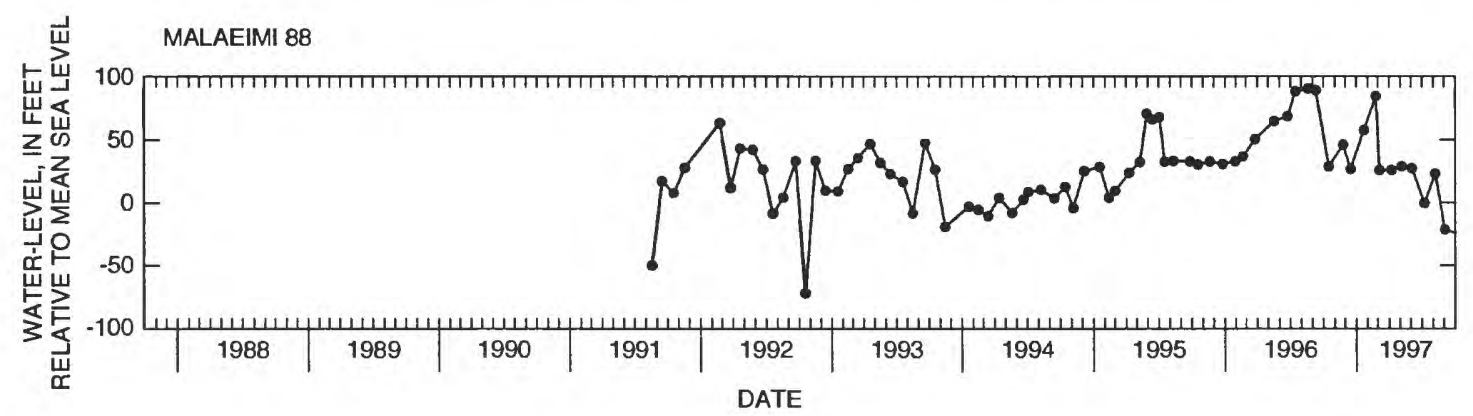

Figure 7. Ground-water levels in the Malaeimi-Mesepa area, Tutuila, American Samoa. (Connecting lines provided only as a visual aid and do not imply interpolation between data points. Data from the American Samoa Power Authority.)

Trends during the 12-month period ending September 1997.--The total production from wells in the Malaeimi-Mesepa area averaged $1.6 \mathrm{Mgal} / \mathrm{d}$ in the $12-$ month period ending September 1997 (fig. 6). Wells 67 and 85 continued pumping at rates close to their longterm average rates of 0.3 to $0.6 \mathrm{Mgal} / \mathrm{d}$. Chloride concentrations in water from both wells remained below 60 $\mathrm{mg} / \mathrm{L}$ throughout this period. The highest chloride concentration reported from well $85(50 \mathrm{mg} / \mathrm{L})$ was measured in December 1996.

Well 89 pumped at about $0.5 \mathrm{Mgal} / \mathrm{d}$ until March 1997, and was shut down in April 1997 because of mechanical problems. Chloride concentrations in this well during pumping remained below $40 \mathrm{mg} / \mathrm{L}$ (fig. 6).

Pumpage at well 88 has averaged $0.3 \mathrm{Mgal} / \mathrm{d}$ between October 1996 and September 1997 (fig. 6). Chloride concentrations from this well have varied between 15 and $30 \mathrm{mg} / \mathrm{L}$ during this period.

Water levels in well 88 in the 12-month period ending September 1997, which corresponds approximately to the period when pumping resumed at the well, declined sharply (fig. 7). The water level in the well was as low as $24 \mathrm{ft}$ below mean sea level (October 1997) during this period.

\section{Iliili}

Iliili is on the Tafuna-Leone Plain less than 1 mile from the southern coastline of Tutuila (fig. 3 ). Four wells, $62,76,79$, and 84 have produced a total of about 1.2 Mgal/d since 1987 (fig. 8). Chloride concentrations at wells 62,76 , and 79 have remained below $250 \mathrm{mg} / \mathrm{L}$ over this period. Chloride concentrations in well 84 frequently exceeded $500 \mathrm{mg} / \mathrm{L}$ and show a gradually increasing trend since 1987. Water levels monitored at well 115 have varied by $\pm 2 \mathrm{ft}$ around a median of about $5 \mathrm{ft}$ (fig. 9).

Trends during the 12-month period ending September 1997.--During the 12-month period ending September 1997, total production from wells in Iliili averaged 1.1 Mgal/d. Pumpage at wells 62,79 , and 84 continued at about the same rate as in the previous 3 years (fig. 8). Well 76 continued to pump at about 0.3 $\mathrm{Mgal} / \mathrm{d}$ as it had since April 1996. Chloride concentrations in wells 62, 76, and 79 declined in late 1996, but from then until September 1997 fluctuated a few tens of milligrams per liter around a median of about $100 \mathrm{mg} / \mathrm{L}$. Chloride concentrations in well 84 continued on a gradual rising trend that began in 1987. Water levels at well 115 during this period continued to show the same variation of 1 to $2 \mathrm{ft}$ around a median of about $5 \mathrm{ft}$ above mean sea level, as in the previous 9 years (fig. 9).

\section{Malaeloa-Leone}

The Malaeloa-Leone area (fig. 3 ) has six production wells, $70,80,91,92,93$, and 119 , which have pumped a total of about $2.2 \mathrm{Mgal} / \mathrm{d}$ since 1987 (fig. 10). Chloride concentrations in wells $70,80,91$, and 92 have remained under $100 \mathrm{mg} / \mathrm{L}$ over the entire period of pumping. Chloride concentrations in well 93 have risen periodically to about $100 \mathrm{mg} / \mathrm{L}$ during periods of lowerthan-average rainfall (compare with Aasufou rainfall record, fig. 2), but remained below $50 \mathrm{mg} / \mathrm{L}$ over most of the pumping period. 
ILIILI 62

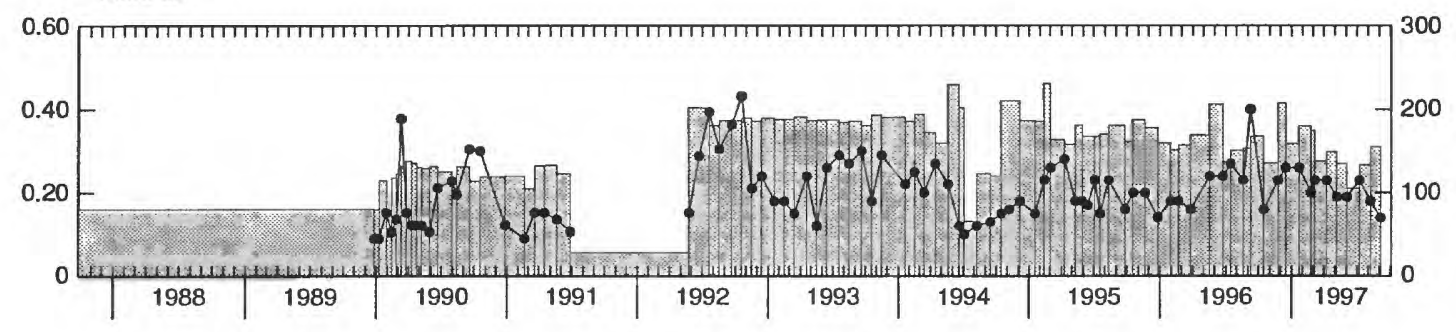

ILIILI 76

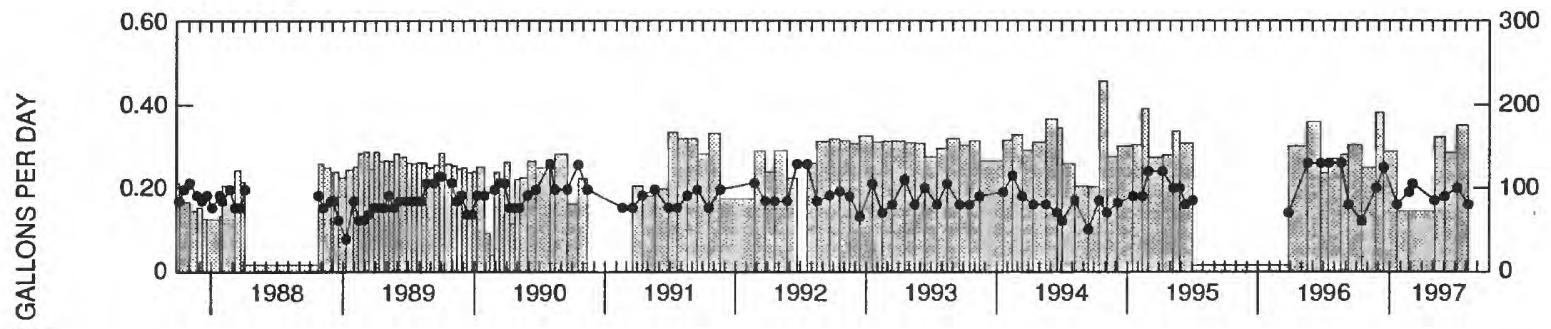

ILIILI 79

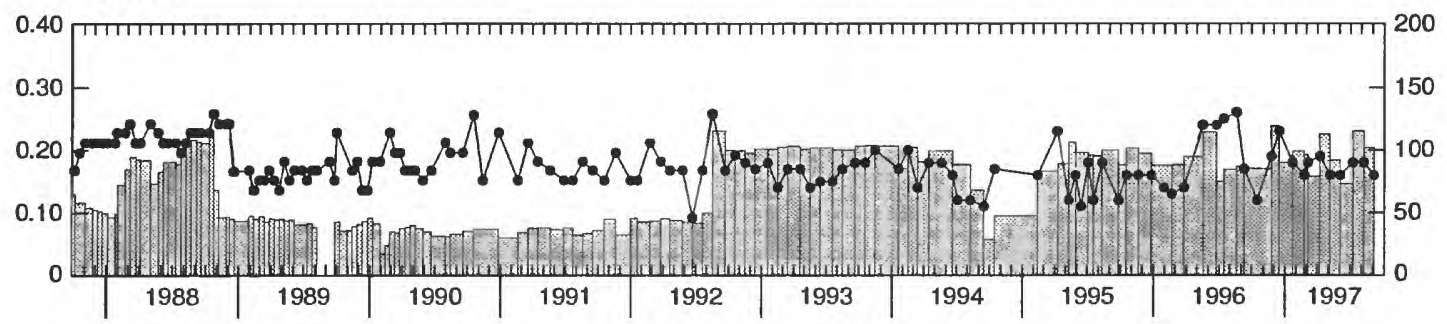

ILIILI 84

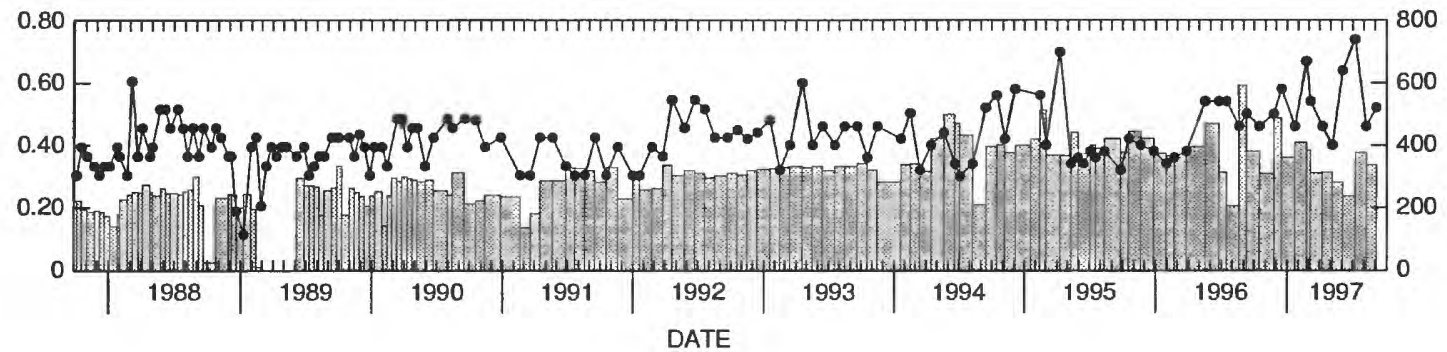

Figure 8. Ground-water pumpage and chloride concentrations in Iliili, Tutuila, American Samoa. (Connecting lines provided only as a visual aid and do not imply interpolation between data points. Connecting lines omitted where period between successive data points exceeds 6 months. Data from the American Samoa Power Authority.) 


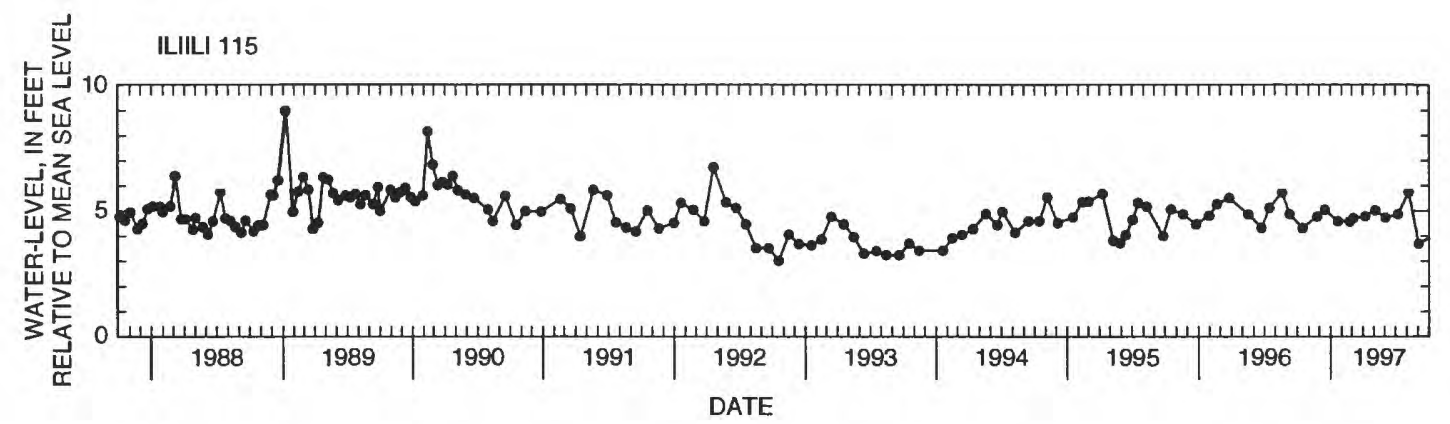

Figure 9. Ground-water levels in Iliili, Tutuila, American Samoa. (Connecting lines provided only as a visual aid and do not imply interpolation between data points. Data from the American Samoa Power Authority.)

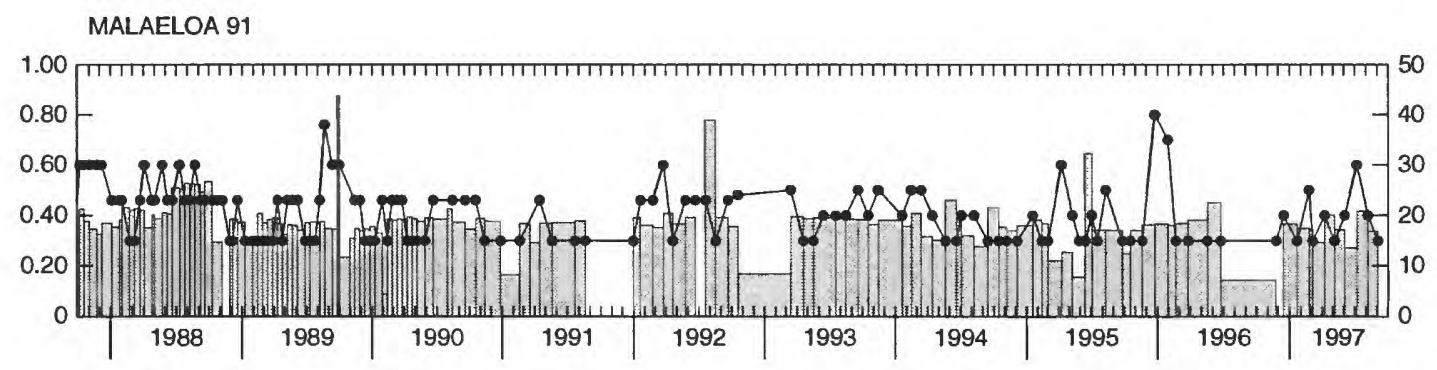

MALAELOA 92



\section{MALAELOA 93}

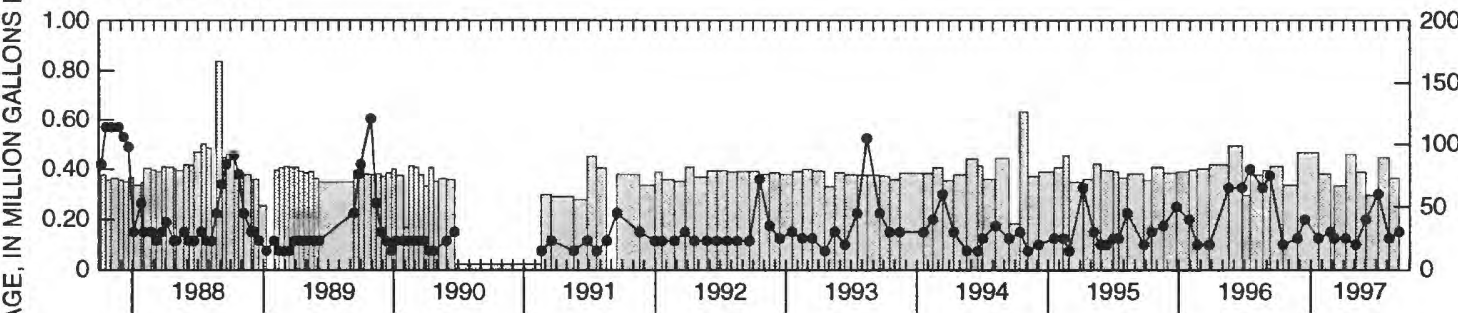

$\sum_{0}^{0}$

\section{MALAELOA 119}

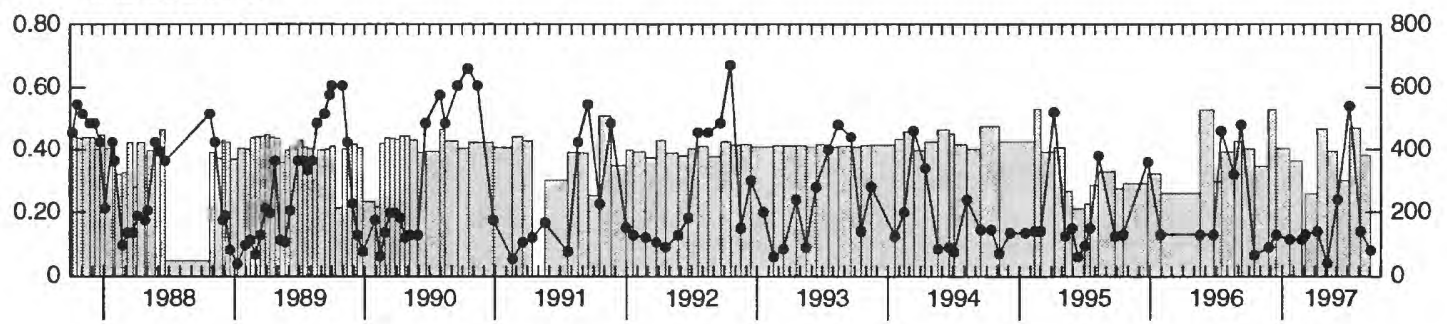

DATE

Figure 10. Ground-water pumpage and chloride concentrations in the Malaeloa-Leone area, Tutuila, American Samoa. (Connecting lines provided only as a visual aid and do not imply interpolation between data points. Connecting lines omitted where period between successive data points exceeds 6 months. Data from the American Samoa Power Authority.) 

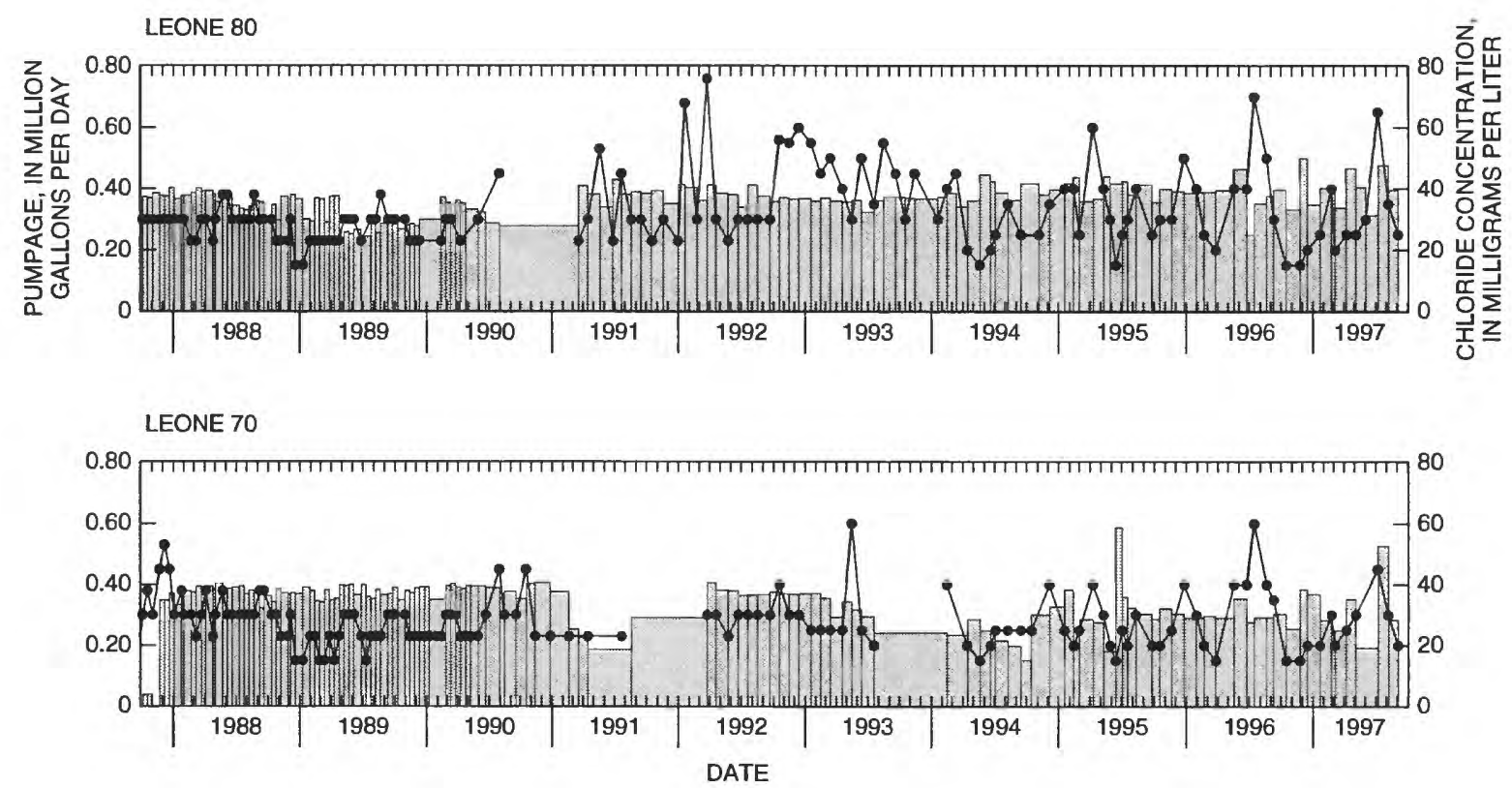

Figure 10. Ground-water pumpage and chloride concentrations in the Malaeloa-Leone Area, Tutuila, American Samoa. (Connecting lines provided only as a visual aid and do not imply interpolation between data points. Connecting lines omitted where period between successive data points exceeds 6 months. Data from the American Samoa Power Authority.) -- Continued

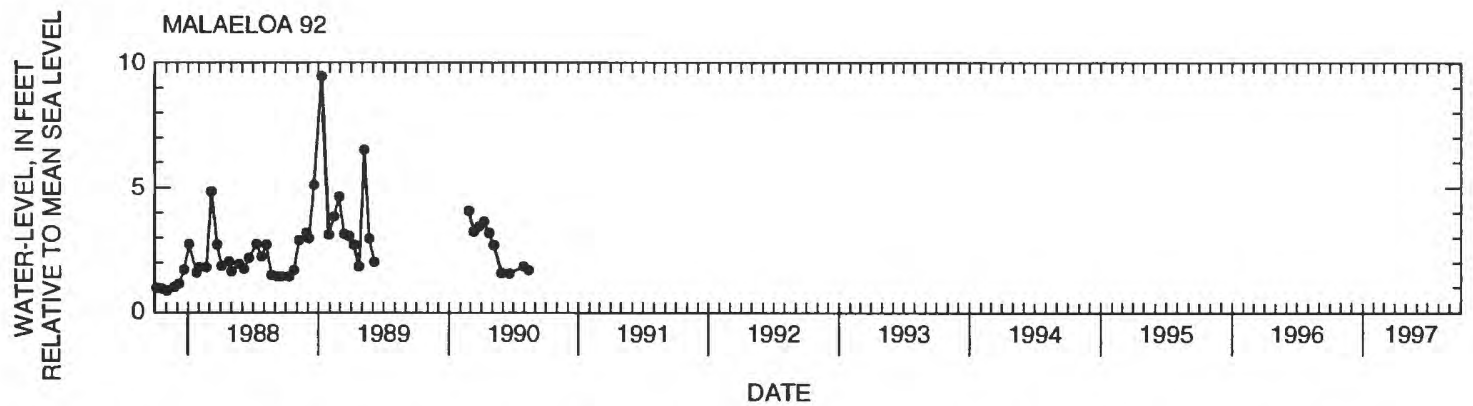

Figure 11. Ground-water levels in Malaeloa, Tutuila, American Samoa. (Connecting lines provided only as a visual aid and do not imply interpolation between data points. Connecting lines omitted where period between successive data points exceeds 6 months. Data from the American Samoa Power Authority.)

Chloride concentrations in well 119 have exceeded $500 \mathrm{mg} / \mathrm{L}$ several times during the period of record (fig. 10). As in well 93, the chloride concentrations in well 119 peaked during periods of lower-than-average rainfall, except that the peaks were more frequent and rose to higher concentrations at well 119. Time-series graphs of chloride concentration in both well 93 and well 119 show a sawtooth pattern similar to the pattern seen in the Tafunafou chloride-concentration record.
Water levels were monitored at well 92 until 1990, during which time water levels fluctuated 1 to $10 \mathrm{ft}$ above mean sea level (fig. 11). Water levels have not been monitored in this area since 1990 .

Trends during the 12-month period ending September 1997.--During the 12-month period ending September 1997, total production from wells in the Malaeloa-Leone area averaged $2.0 \mathrm{Mgal} / \mathrm{d}$ (fig. 10). Pumpage at wells 70, 80, and 93 in the Malaeloa-Leone 


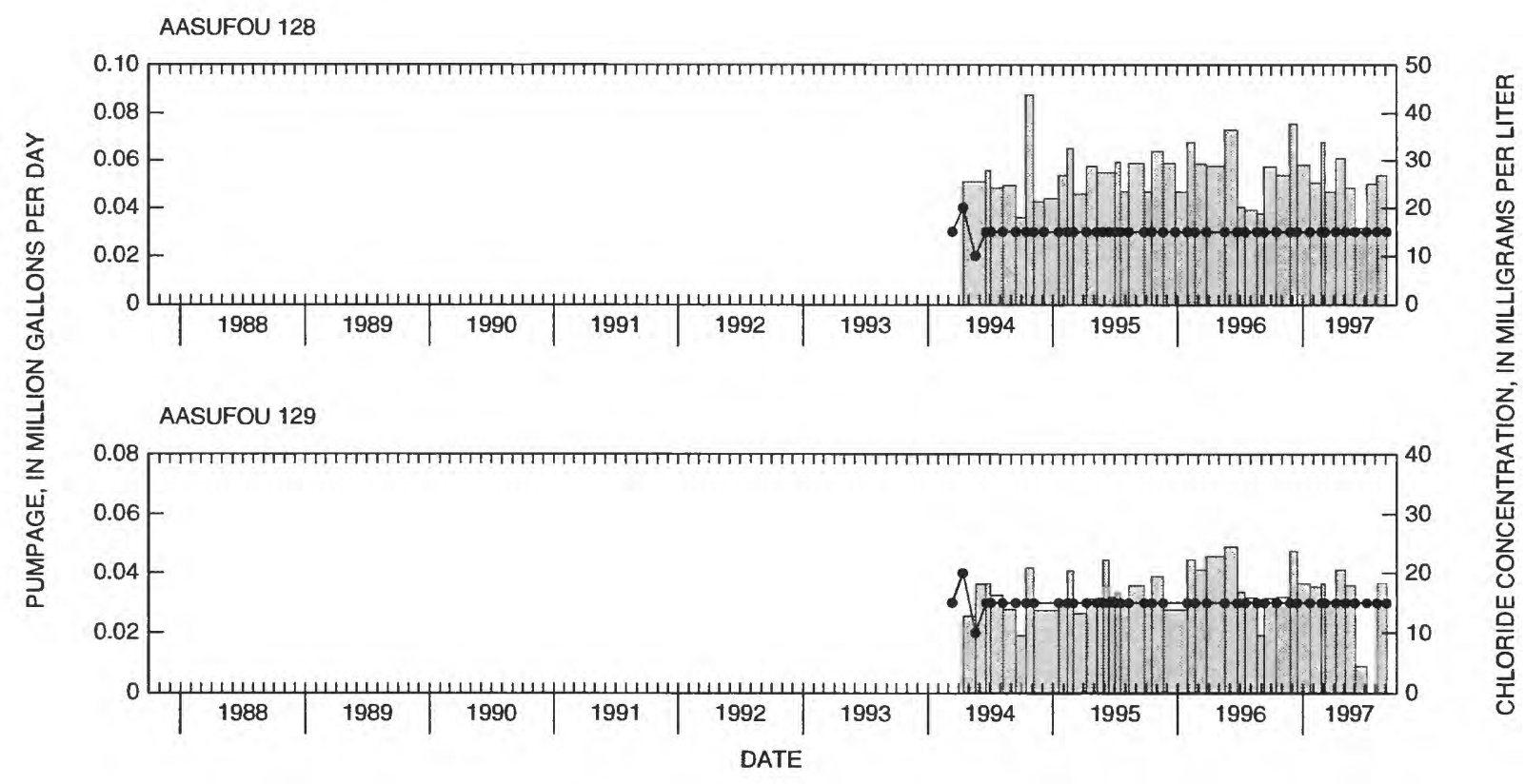

Figure 12. Ground-water pumpage and chloride concentrations in Aasufou, Tutuila, American amoa. (Connecting lines provided only as a visual aid and do not imply interpolation between data points. Data from the American Samoa Power Authority.)

area was about the same as in previous years shown in the graphs in figure 10. Pumpage at well 119 was higher than in mid-1995 to mid-1996. Pumpage at well 91 was halted near the end of 1996, but resumed in 1997 at about the same rate $(0.4 \mathrm{Mgal} / \mathrm{d})$ as in the previous 9 years. Pumpage at well 92 was reduced and stopped in late 1996 and early 1997, but resumed in February 1997 at about $0.3 \mathrm{Mgal} / \mathrm{d}$.

Chloride concentrations in all wells except well 119 remained below $100 \mathrm{mg} / \mathrm{L}$ during the 12 -month period ending September 1997. Chloride concentrations in well 119 were below $250 \mathrm{mg} / \mathrm{L}$ during most of this period, except in July 1997 when chloride concentrations reached $540 \mathrm{mg} / \mathrm{L}$.

\section{Aasufou}

Wells 128 and 129 in Aasufou develop water from pyroclastic deposits at the crest of Olotele Mountain (fig. 3). The wells have pumped about 0.03 to 0.05 Mgal/d each since they were put in production in 1994 (fig. 12). Chloride concentrations have remained less than $20 \mathrm{mg} / \mathrm{L}$ throughout most of the pumping period. No water levels have been reported for Aasufou.
Trends during the 12-month period ending September 1997.--During the 12-month period ending September 1997, pumpage averaged $0.05 \mathrm{Mgal} / \mathrm{d}$ at well 128 and $0.030 \mathrm{Mgal} / \mathrm{d}$ at well 129 , which is the same as the average rate of pumpage since the wells began production in 1994 (fig. 12). Chloride concentrations in both wells have remained at $15 \mathrm{mg} / \mathrm{L}$ throughout this period.

\section{CENTRAL TUTUILA GROUND-WATER DATA}

Most of the wells in central Tutuila lie in small valleys surrounding the embayment of Pago Pago Harbor (fig. 13). Wells in Fagaalu, Fagatogo, Pago Pago, and Aua lie in valleys whose mouths form smaller embayments nested within the larger embayment of Pago Pago Harbor. To the north of the harbor a high cliff extends eastward from Pago Pago to Aua. Fagasa and Laulii lie in valleys outside the drainage area of Pago Pago Harbor.

Because of the large natural harbor in Pago Pago, central Tutuila is the industrial center on the island. Villages lie mostly on the relatively flat valley floors and 


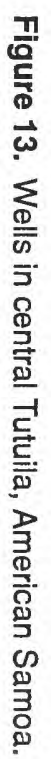




coastal plain and extend a short distance up the adjoining hillsides. Ground water is developed mostly from wells in the valleys, but a pipeline connects the southern shore of central and eastern Tutuila with the more productive wells of western Tutuila. The wells in Fagasa are not connected to this pipeline.

\section{Fagaalu}

Ground-water in Fagaalu on the western side of Pago Pago Harbor (fig. 13) is produced from well 127, which has been pumped intermittently at an average of about $0.05 \mathrm{Mgal} / \mathrm{d}$ since late 1992 (fig. 14). Chloride concentrations from this well remained below $100 \mathrm{mg} / \mathrm{L}$ during this period.

Water levels in Fagaalu have been monitored at well 126 since 1987 (fig. 15). Before 1989, water levels at well 126 were between 70 and $80 \mathrm{ft}$ above mean sea level. The well was deepened in 1989 and the upper part sealed to prevent seepage from a nearby stream. After the well was sealed, the water level dropped to about 25 $\mathrm{ft}$ above mean sea level, then climbed to about $60 \mathrm{ft}$ between 1989 and 1991. Between 1991 and early 1996, water levels remained near $60 \mathrm{ft}$ above mean sea level, then dropped sharply to about $30 \mathrm{ft}$. Reasons for this second sharp drop are not yet known.

Trends during the 12-month period ending September 1997.--Pumpage at well 127 rose sharply in mid-1996 (fig. 14). In the 12-month period ending September 1997, pumpage at well 127 averaged 0.13 $\mathrm{Mgal} / \mathrm{d}$, which is more than double the average pumpage of the previous 4 years $(0.05 \mathrm{Mgal} / \mathrm{d})$. Pumpage in August and September 1997 exceeded 0.20 Mgal/d. Chloride concentrations in water from the well have continued on an increasing trend that began in mid1995, although the concentrations did not exceed 100 $\mathrm{mg} / \mathrm{L}$.

After water levels in monitor well 126 dropped to about $30 \mathrm{ft}$ above mean sea level in early 1996 , water levels fluctuated within a few tens of feet of this elevation through September 1997 (fig. 15).

\section{Fagatogo}

Pumpage in the Fagatogo area (fig. 13) has alternated between wells 101 and 102 . Well 101 produced about $1 \mathrm{Mgal} / \mathrm{d}$ from 1986 to 1988 . From 1988 to 1992 , well 101 was shut off and well 102 was pumped at a rate of about $0.9 \mathrm{Mgal} / \mathrm{d}$ (fig. 16). Pumpage was switched back to well 101 in 1992 but reduced to about 0.5 $\mathrm{Mgal} / \mathrm{d}$. Chloride concentrations at both pumped wells remained mostly below $50 \mathrm{mg} / \mathrm{L}$ throughout the period of record.

Water levels monitored in well 101 in 1986 prior to the beginning of pumping were about $20 \mathrm{ft}$ above mean sea level (Izuka, 1996, 1997). Between 1988 and 1992, when well 102 was being pumped and well 101 was used only for water-level monitoring, water levels in well 101 were near mean sea level, and occasionally dropped 2 to $3 \mathrm{ft}$ below mean sea level (fig. 17). For a brief period in mid-1992, pumping at both 101 and 102 ceased, and water levels in well 101 began to rise.

Trends during the 12-month period ending September 1997.--Pumping at well 101 during the 12month period ending September 1997 continued at about $0.5 \mathrm{Mgal} / \mathrm{d}$, which is about the same rate as in previous years since pumping resumed in 1992 (fig. 16). Chloride concentrations in the well have remained under $50 \mathrm{mg} / \mathrm{L}$.

\section{Pago Pago}

Pago Pago, located at the farthest inland extension of the Pago Pago Harbor embayment, has production wells 105, 107, 163, and 165 (fig. 13). Between 1988 and 1995, well 105 was pumped at a rate of about 0.2 $\mathrm{Mgal} / \mathrm{d}$, except when pumping was halted briefly in late 1991. Beginning in mid-1995, the well was pumped intermittently. Well 107 has been pumped at about 0.5 $\mathrm{Mgal} / \mathrm{d}$ (fig. 18) since late 1988 . Well 163 began pumping in mid-1995 at about $0.4 \mathrm{Mgal} / \mathrm{d}$, and a new production well, 165, began pumping in late 1997. All of the Pago Pago wells have maintained chloride concentrations of less than $50 \mathrm{mg} / \mathrm{L}$ throughout their periods of record.

Pre-pumping water levels at well 105 fluctuated between 47 and $50 \mathrm{ft}$ above mean sea level (fig. 19). Pumping water levels are not available at well 105. Water levels at well 107 during pumping initially declined from about $20 \mathrm{ft}$ to about $3 \mathrm{ft}$ above mean sea level and dropped as low as $1 \mathrm{ft}$ below mean sea level between 1989 and 1990, but have remained at about $5 \mathrm{ft}$ above mean sea level since then. 
FAGAALU 127

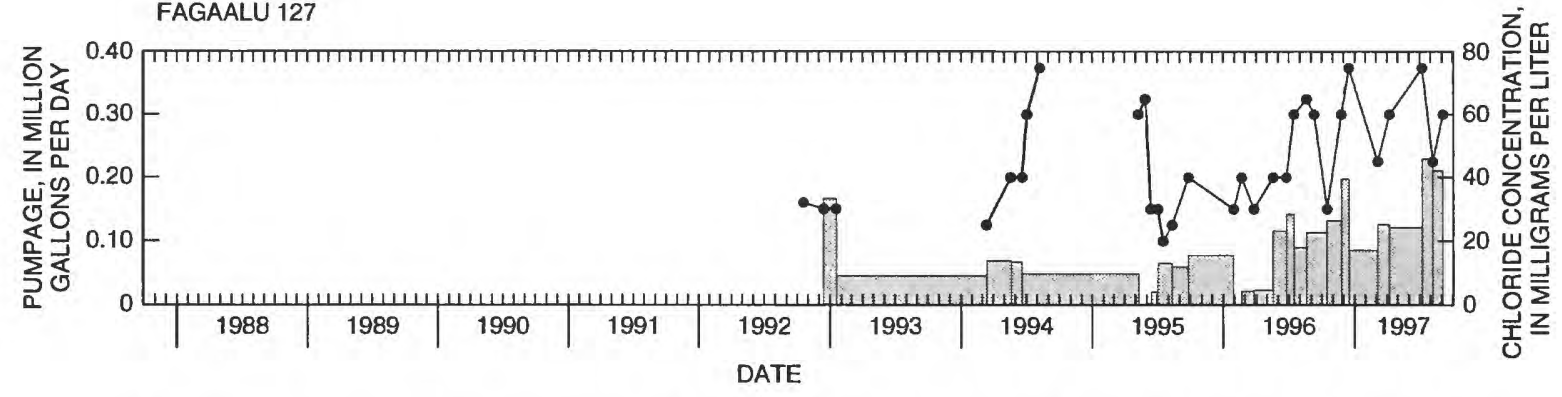

DATE

Figure 14. Ground-water pumpage and chloride concentrations in Fagaalu, Tutuila, American Samoa. (Connecting lines provided only as a visual aid and do not imply interpolation between data points.

Connecting lines omitted where period between successive data points exceeds 6 months. Data from the American Samoa Power Authority.)

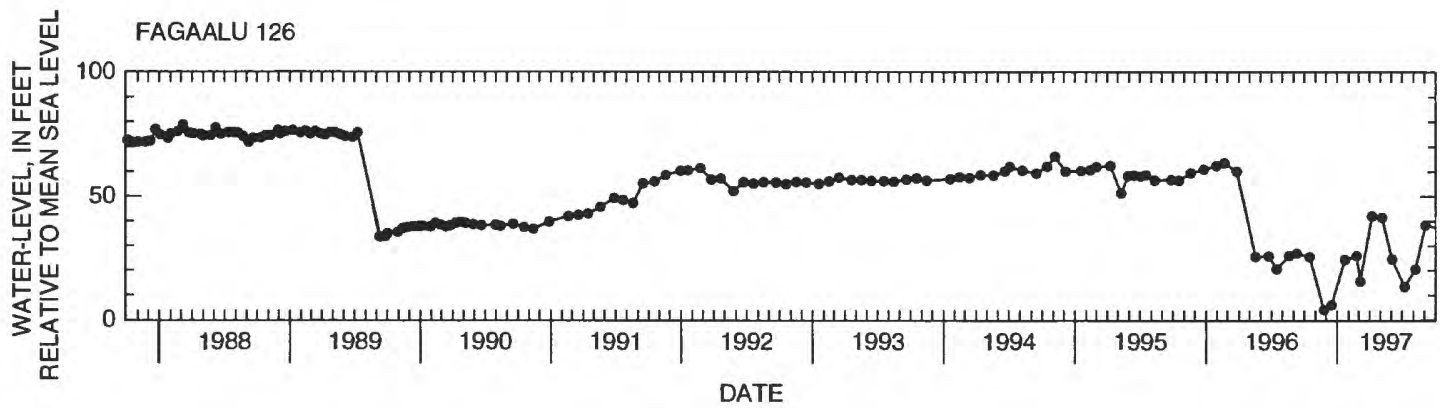

Figure 15. Ground-water levels in Fagaalu, Tutuila, American Samoa. (Connecting lines provided only as a visual aid and do not imply interpolation between data points. Connecting lines omitted where period between successive data points exceeds 6 months. Data from the American Samoa Power Authority.)

FAGATOGO 101

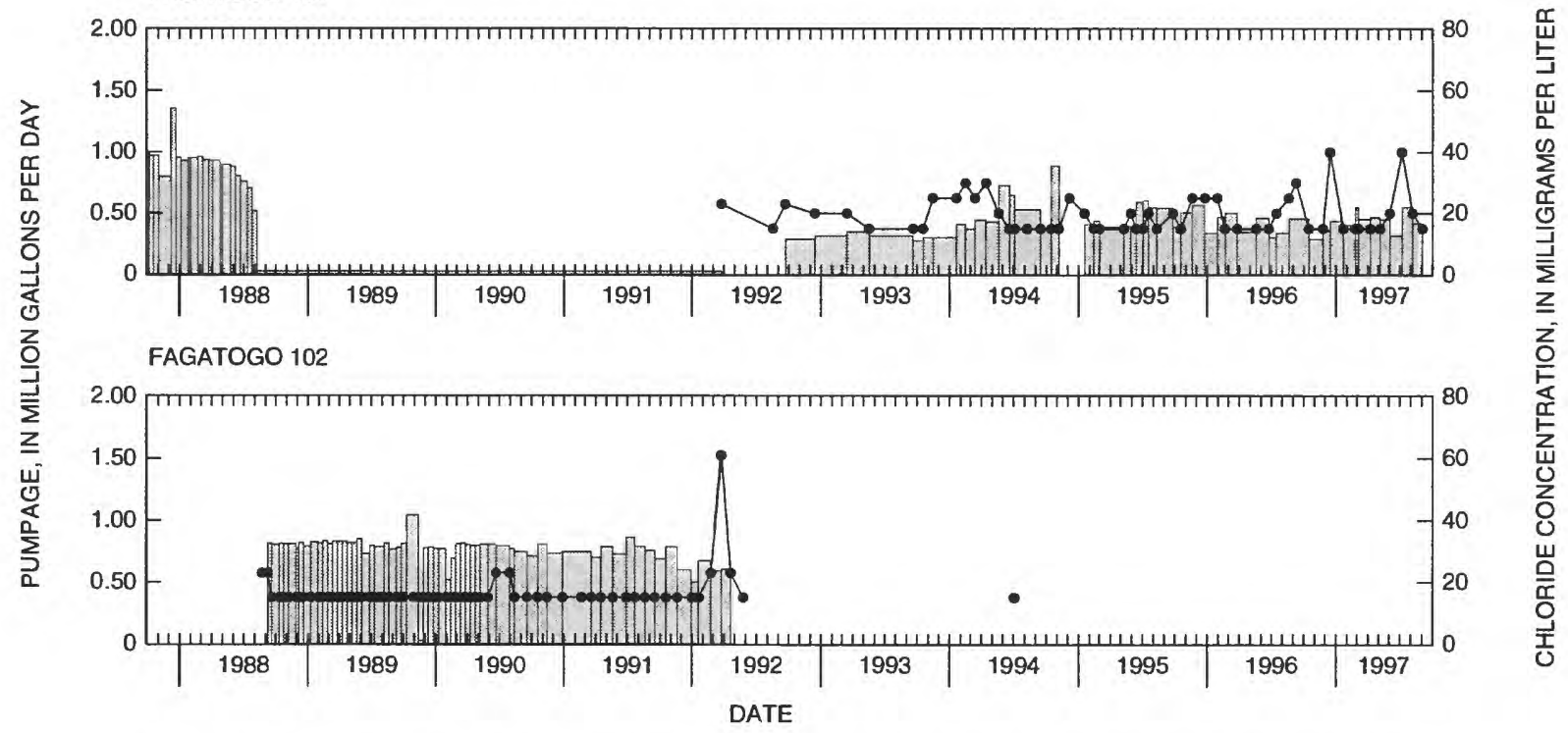

Figure 16. Ground-water pumpage and chloride concentrations in Fagatogo, Tutuila, American Samoa. (Connecting lines provided only as a visual aid and do not imply interpolation between data points. Data from the American Samoa Power Authority.) 


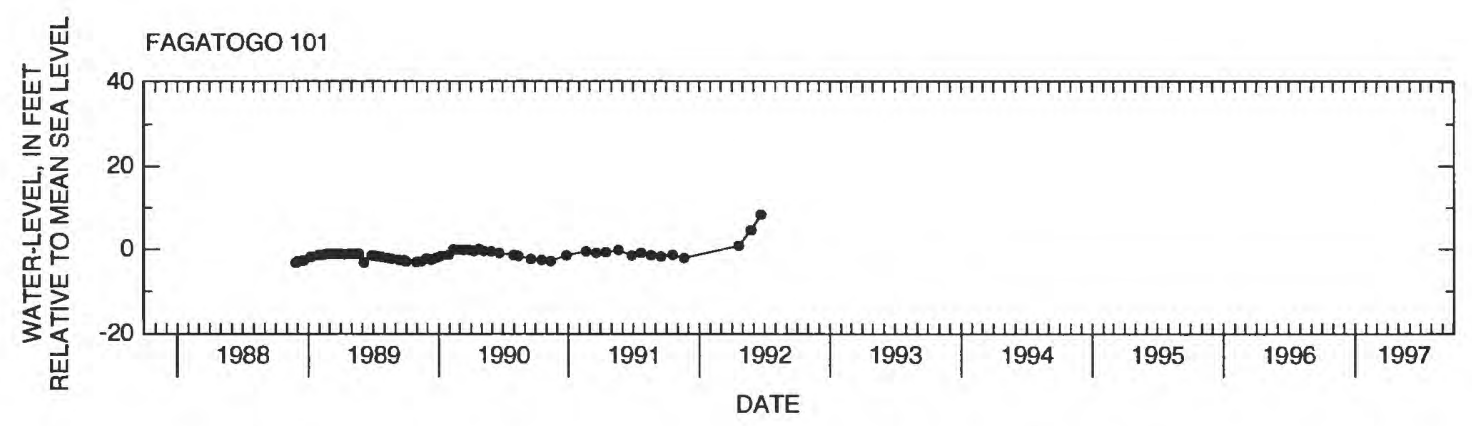

Figure 17. Ground-water levels in Fagatogo, Tutuila, American Samoa. (Connecting lines provided only as a visual aid and do not imply interpolation between data points. Data from the American Samoa Power Authority.)

PAGO PAGO 105

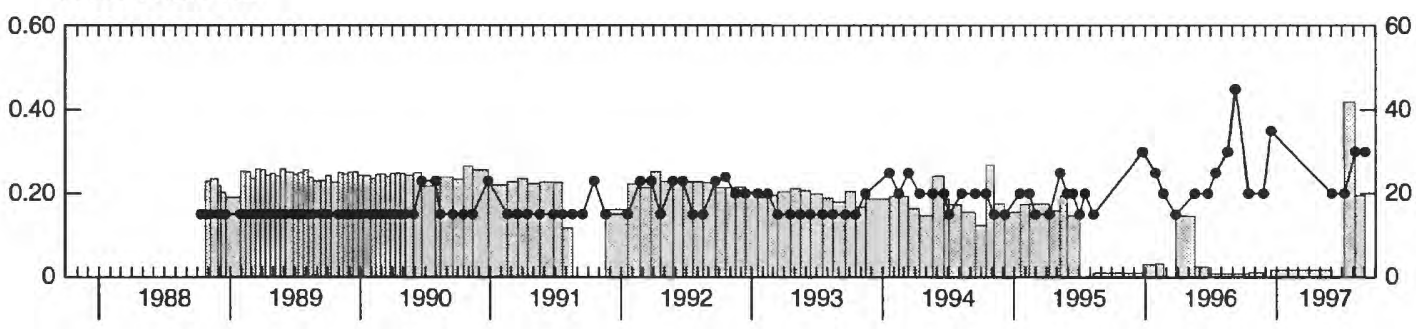

PAGO PAGO 107



PAGO PAGO 163

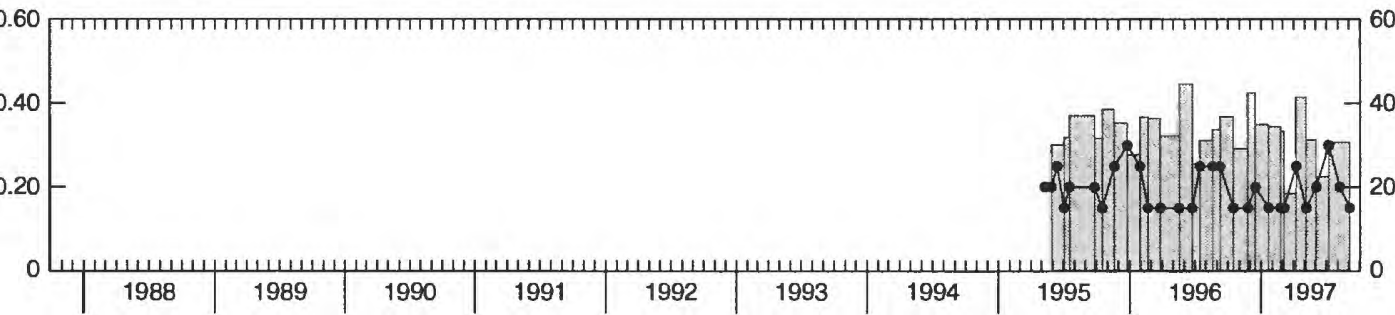

PAGO PAGO 165

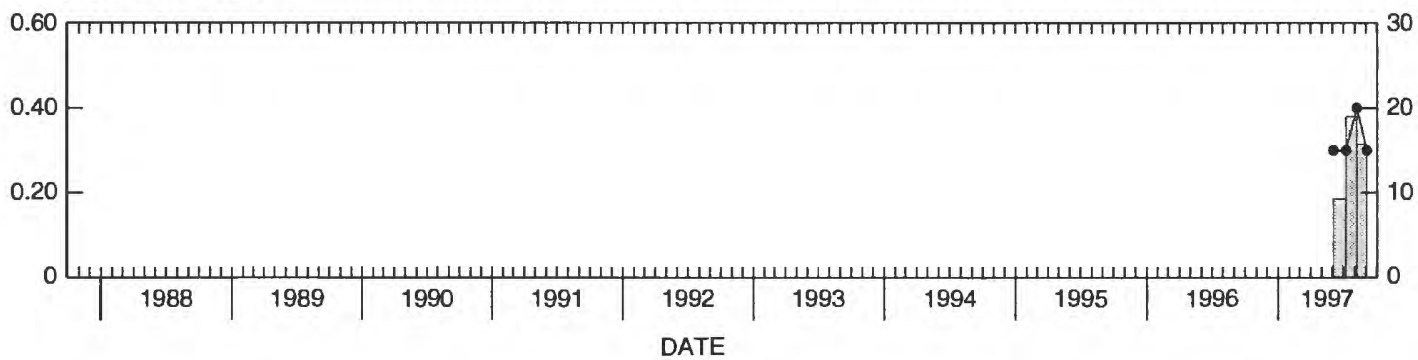

Figure 18. Ground-water pumpage and chloride concentrations in Pago Pago, Tutuila, American Samoa. (Connecting lines provided only as a visual aid and do not imply interpolation between data points. Data from the American Samoa Power Authority.) 


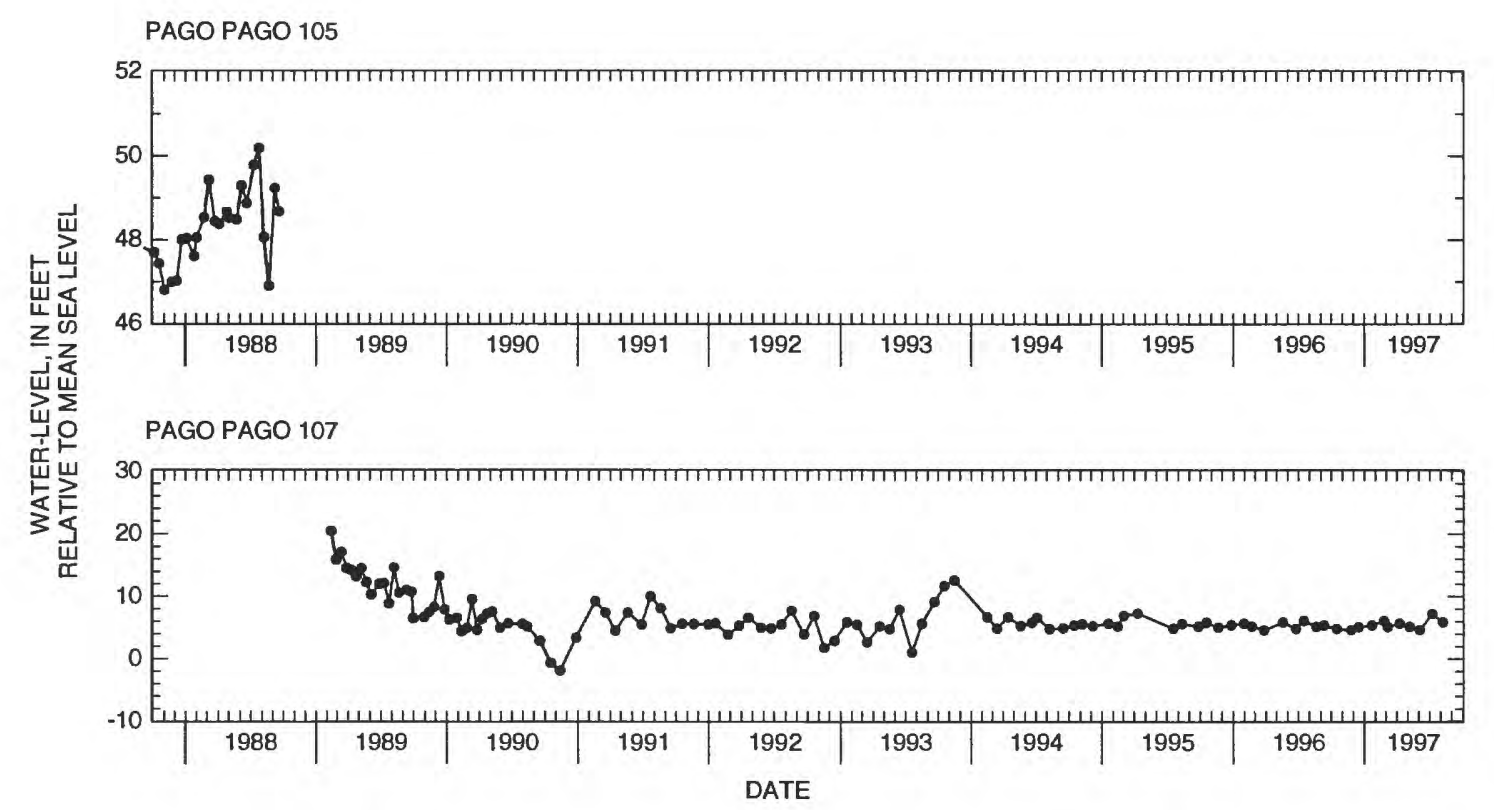

Figure 19. Ground-water levels in Pago Pago, Tutuila, American Samoa. (Connecting lines provided only as a visual aid and do not imply interpolation between data points. Data from the American Samoa Power Authority.)

Trends during the 12-month period ending September 1997.-- In late 1996 through early 1997 , well 105 was pumped intermittently at an average rate of $0.02 \mathrm{Mgal} / \mathrm{d}$ as it had been since 1995 , but in mid-1997, pumping was increased to 0.2 to $0.4 \mathrm{Mgal} / \mathrm{d}$. In the $12-$ month period ending September 1997, pumpage at well 107 averaged $0.5 \mathrm{Mgal} / \mathrm{d}$, which is about the same rate maintained since 1988, and pumpage at well 163 averaged $0.3 \mathrm{Mgal} / \mathrm{d}$, about the same rate since 1995 (fig. 18). Pumpage at the new well (165) averaged 0.3 $\mathrm{Mgal} / \mathrm{d}$.

Chloride concentrations in well 105 fluctuated, but did not exceed $50 \mathrm{mg} / \mathrm{L}$. Chloride concentrations in wells 107 and 165 during the 12-month period ending September 1996 have remained near $20 \mathrm{mg} / \mathrm{L}$ with fluctuations of about $10 \mathrm{mg} / \mathrm{L}$. Chloride concentrations at the new well (165) ranged between 15 and $20 \mathrm{mg} / \mathrm{L}$. Water levels monitored at well 107 remained at about 5 ft above mean sea level, as it has since 1994 (fig. 19).

\section{Aua}

Aua (fig. 13) has two wells that have pumpage records between October 1987 and September 1997. Well 97 began pumping in 1984 and well 99 began pumping in 1985 (Izuka, 1996, 1997). Pumpages and chloride concentrations at the wells have varied greatly since pumping began. Pumpage at well 97 began at about $0.4 \mathrm{Mgal} / \mathrm{d}$ and initial chloride concentrations were below $100 \mathrm{mg} / \mathrm{L}$, but after about 2 years of steady pumping, chloride concentrations began rising sharply. By late 1987, pumpage at well 97 had been halted because of rising chloride concentrations, and between 1987 and 1990, the well was pumped only intermittently. Chloride concentrations at the well decreased slowly when pumpage was lowered or halted, but quickly rose again when pumpage resumed. In 1991 pumping resumed at a more constant rate of about 0.4 $\mathrm{Mgal} / \mathrm{d}$, and chloride concentrations rose to more than $500 \mathrm{mg} / \mathrm{L}$, occasionally exceeding $800 \mathrm{mg} / \mathrm{L}$.

Pumpage at well 99 began in 1985 at about 0.3 Mgal/d (Izuka, 1996, 1997). As in well 97, initial chloride concentrations were below $100 \mathrm{mg} / \mathrm{L}$, but began steadily rising after about $1 \frac{1}{2}$ years. In late 1987 , well 99 was still pumping at about $0.3 \mathrm{Mgal} / \mathrm{d}$ and this pumping rate continued with few decreases to about 1989 (fig. 20). By late 1987, chloride concentrations were in excess of $400 \mathrm{mg} / \mathrm{L}$ and remained near $400 \mathrm{mg} / \mathrm{L}$ most of the time from 1988 through 1990, even several months after pumpage was reduced to about $0.2 \mathrm{Mgal} / \mathrm{d}$ in 1989. Chloride concentrations began declining in 1990 and by 1991 , the chloride concentrations were near $200 \mathrm{mg} / \mathrm{L}$. Chloride concentrations stayed at 100 to $200 \mathrm{mg} / \mathrm{L}$ until mid-1994 when pumpage was increased 


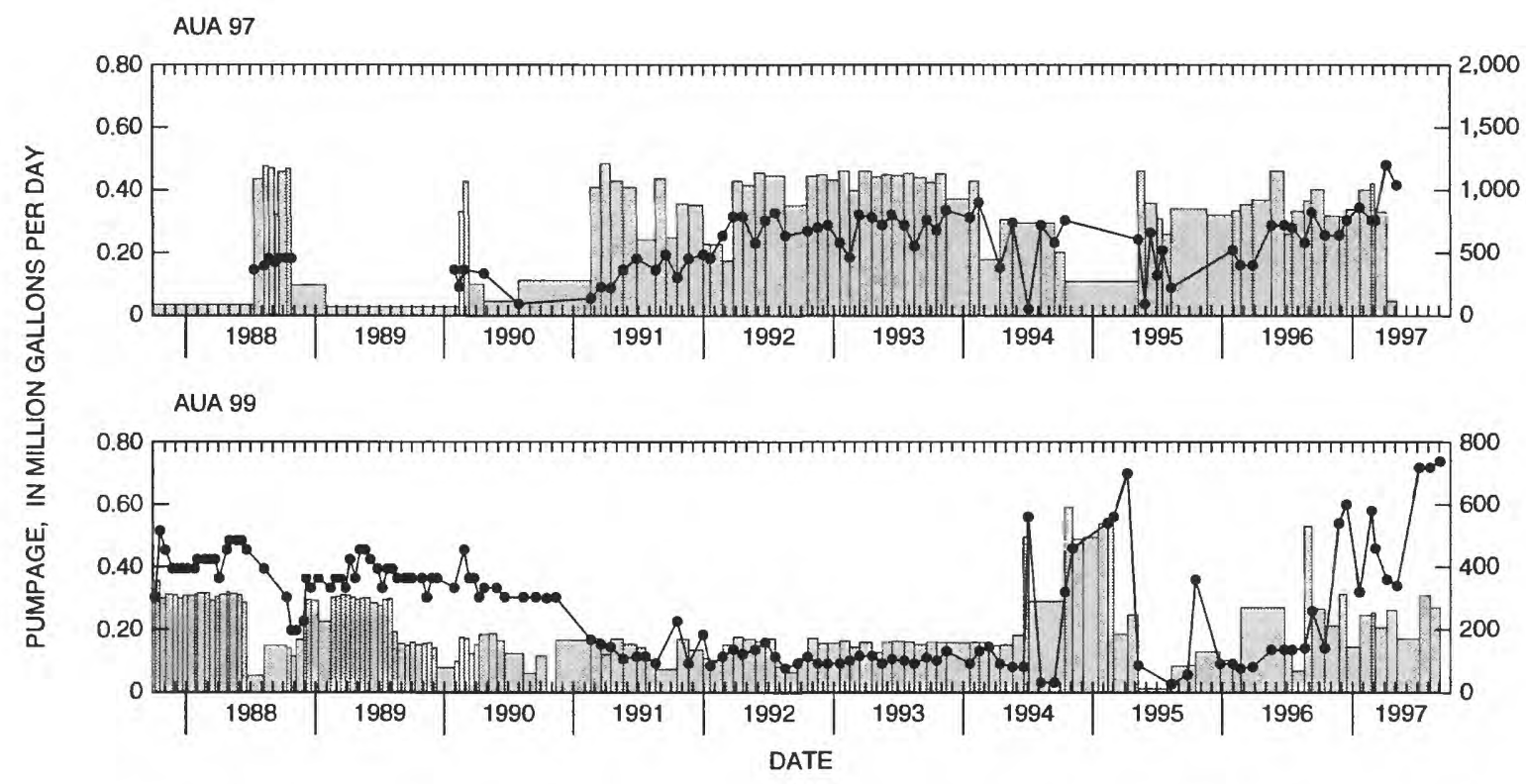

Figure 20. Ground-water pumpage and chloride concentrations in Aua, Tutuila, American Samoa. (Connecting lines provided only as a visual aid and do not imply interpolation between data points. Connecting lines omitted where period between successive data points exceeds 6 months. Data from the American Samoa Power Authority.)

to $0.5 \mathrm{Mgal} / \mathrm{d}$ and chloride concentration rose to more than $500 \mathrm{mg} / \mathrm{L}$.

Water levels monitored in pumping well 99 in late 1985 through 1989 are nearly all below mean sea level, some by as much as $60 \mathrm{ft}$ (Izuka, 1996, 1997). Water levels measured in non-pumping well 98 began declining and have fallen to about 15 to $20 \mathrm{ft}$ below mean sea level since nearby well 97 returned to production in 1991. Water levels measured at non-pumping well 103 have mostly remained a few feet above mean sea level but occasionally dropped a few feet below mean sea level during the period 1987 to 1992 (fig. 21).

Trends during the 12-month period ending September 1997. -- From October 1996 through April 1997, pumpage at well 97 averaged $0.4 \mathrm{Mgal} / \mathrm{d}$, which is about the same rate as in previous months since mid1995 (fig. 20). Chloride concentrations in well 97 continued on a rising trend that began in 1995 and reached the highest concentration on record for the well $(1,200$ $\mathrm{mg} / \mathrm{L})$ in April 1997. Pumpage at the well was halted in May 1997.

Between October 1996 and September 1997, pumpage at well 99 averaged $0.2 \mathrm{Mgal} / \mathrm{d}$, which is an increase compared with the average of the previous 12 months (fig. 20). Chloride concentrations in well 99 continued on an increasing trend that began in 1995 and reached the highest concentration on record for the well (740 mg/L) in September 1997.

During the 12-month period ending September 1997, water levels in well 98 were 12 to $15 \mathrm{ft}$ below mean sea level, as they had been since 1995 (fig. 21).

\section{Laulii}

Laulii, on the south coast of Tutuila about $0.5 \mathrm{mi}$ east of Pago Pago Harbor (fig. 13), has one pumping well (96) and one monitor well (106). Pumpage at well 96 averaged $0.07 \mathrm{Mgal} / \mathrm{d}$ through the period of record (fig. 22). Chloride concentrations in this well have remained less than $100 \mathrm{mg} / \mathrm{L}$ over the period of record, but show more variability since 1992 . Water levels at well 96 prior to pumping varied between 18 and $21 \mathrm{ft}$ above mean sea level (fig. 23). Water levels at well 106 have fluctuated between 16 and $28 \mathrm{ft}$ above mean sea level.

Trends during the 12-month period ending September 1997.--Pumpage at well 96 during the 12-month period ending September 1997, averaged $0.08 \mathrm{Mgal} / \mathrm{d}$ which is slightly higher than the average pumpage for the period of record (fig. 22). Chloride concentrations during the 12-month period ending September 1997 


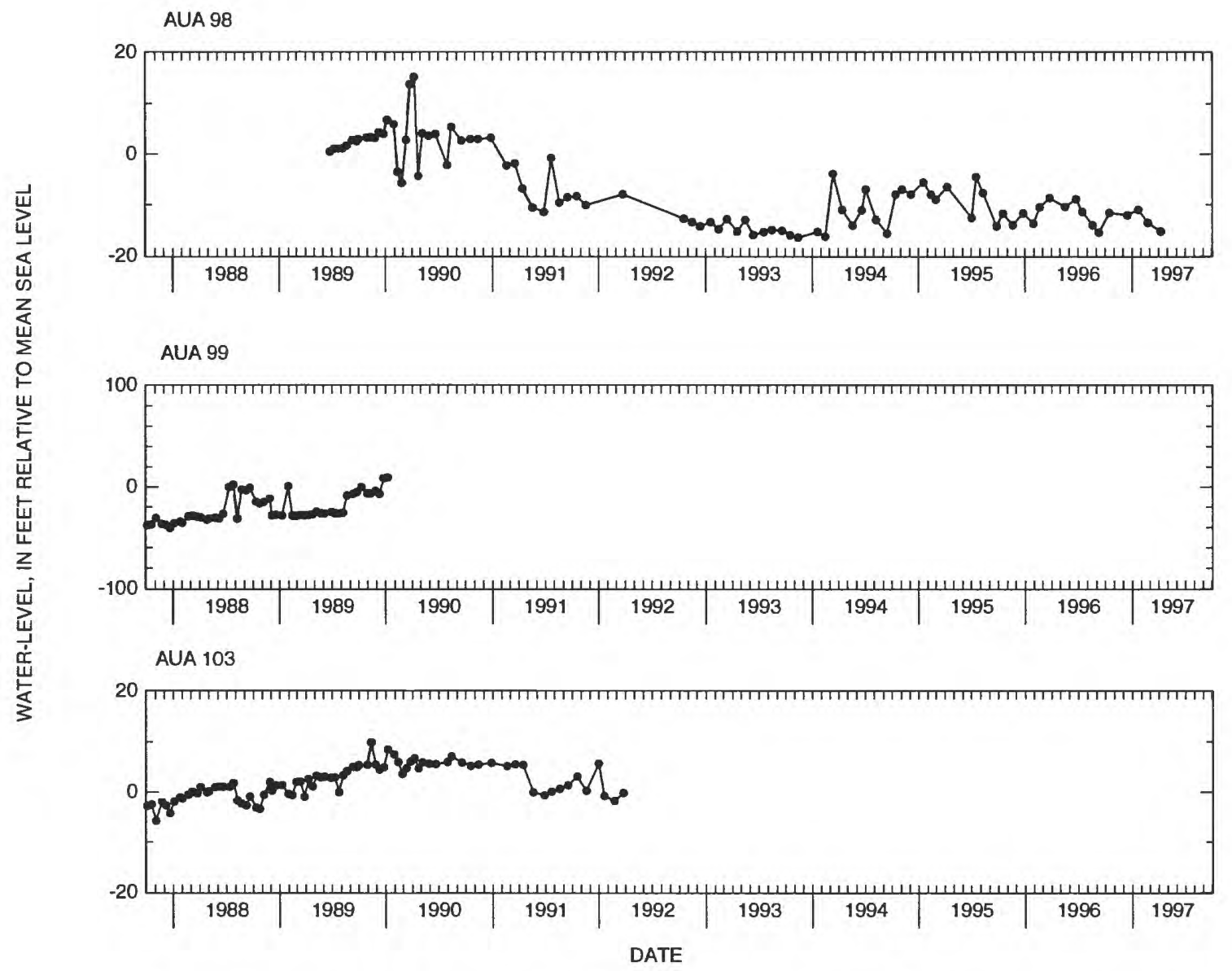

Figure 21. Ground-water levels in Aua, Tutuila, American Samoa. (Connecting lines provided only as a visual aid and do not imply interpolation between data points. Data from the American Samoa Power Authority.)

varied from 20 to $60 \mathrm{mg} / \mathrm{L}$, which is similar to the variation in chloride concentrations recorded at this well since 1982.

Water levels in monitor well 106 during the 12month period ending September 1997 ranged from 16 to $24 \mathrm{ft}$ above mean sea level (fig. 23). The water level measured in November 1996 is the lowest on record for this well. Water levels measured in December 1996, and in May and June 1997 are among the lowest recorded for this well.

\section{Fagasa}

Fagasa is in a small valley on the northern coast of central Tutuila (fig. 13). Well 141 in Fagasa has pumped intermittently with an average of $0.014 \mathrm{Mgal} / \mathrm{d}$ (fig. 24). Chloride concentrations at well 141 remained below $100 \mathrm{mg} / \mathrm{L}$ from 1991 through early 1995 , but fluctuated greatly since then, and occasionally exceeded $400 \mathrm{mg} / \mathrm{L}$.

Well 142 has been pumped intermittently at an average rate of $0.005 \mathrm{Mgal} / \mathrm{d}$ since 1991 , but pumpage has been more persistent in the period from 1994 through 1996 (fig. 24). The range of variation in chloride concentrations at well 142 increased since pumping began in 1991, through 1995, and showed an overall increasing trend. Chloride concentrations at this well decreased sharply in early 1995 corresponding to a brief period of reduced pumpage, then increased again in 1996 when pumpage increased.

Well 143 began pumping in 1997; its pumping rate and chloride concentrations are discussed below.

Trends during the 12-month period ending September 1997.--Pumpage at well 141 averaged 0.021 
LAULII 96

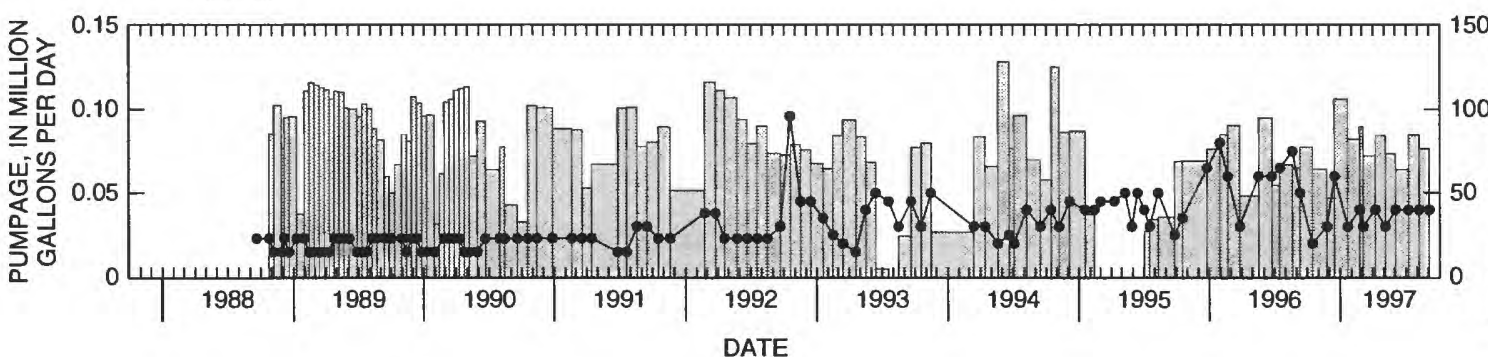

Figure 22. Ground-water pumpage and chloride concentrations in Laulii, Tutuila, American Samoa. (Connecting lines provided only as a visual aid and do not imply interpolation between data points. Data from the American Samoa Power Authority.)

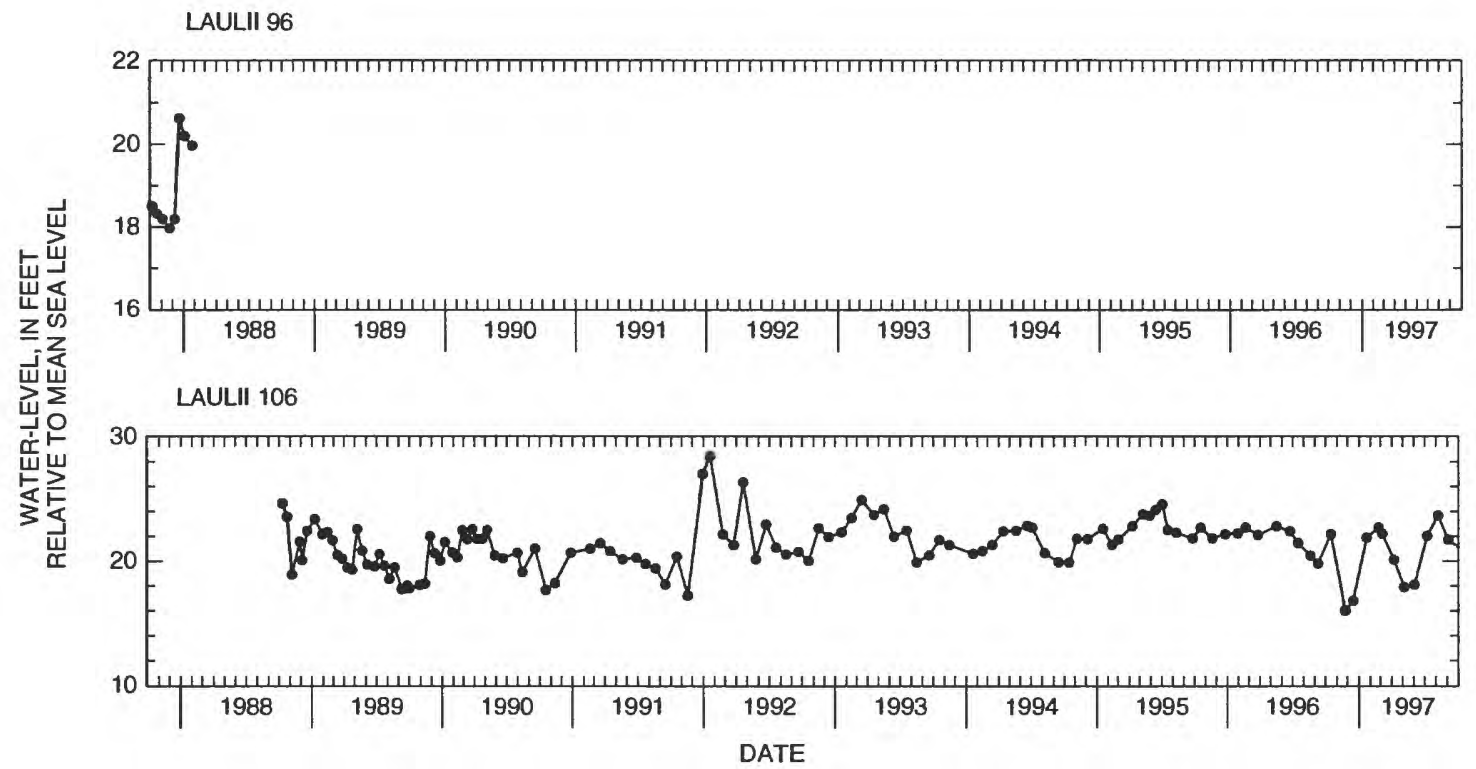

Figure 23. Ground-water levels in Laulii, Tutuila, American Samoa. (Connecting lines provided only as a visual aid and do not imply interpolation between data points. Data from the American Samoa Power Authority.) 


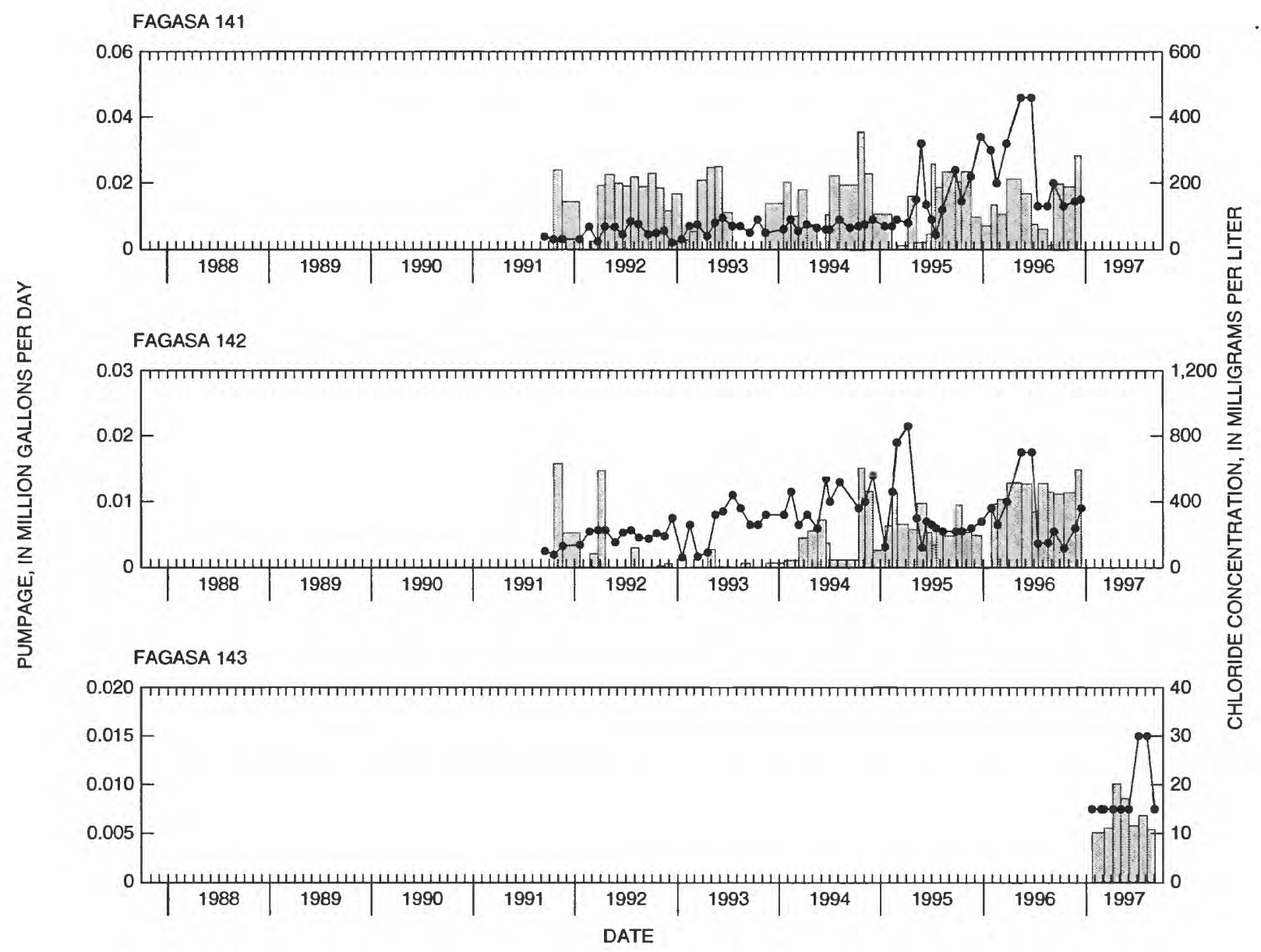

Figure 24. Ground-water pumpage and chloride concentrations in Fagasa, Tutuila, American Samoa. (Connecting lines provided only as a visual aid and do not imply interpolation between data points.

Data from the American Samoa Power Authority.)

Mgal/d from October through December 1996; chloride concentrations ranged from 130 to $150 \mathrm{mg} / \mathrm{L}$ (fig. 24). Pumpage at well 141 was halted in January 1997.

Pumpage at well 142 averaged $0.012 \mathrm{Mgal} / \mathrm{d}$ from October through December 1996; chloride concentrations at this well during this period ranged from 115 to $360 \mathrm{mg} / \mathrm{L}$ (fig. 24). Pumpage at well 142 also was halted in January 1997. Well 143 began pumping in 1997 at an average rate of $0.007 \mathrm{Mgal} / \mathrm{d}$ and had chloride concentrations ranging between 15 and $30 \mathrm{mg} / \mathrm{L}$.

\section{EASTERN TUTUILA AND AUNUU GROUND-WATER DATA}

Eastern Tutuila is formed by steep mountains that rise abruptly from the coastline. Short valleys have been cut into the island by stream erosion. Drowning of the lower parts of the valleys has created many embayments along both the northern and southern coasts (fig. 25). Valley-fill and coastal sediments create the only flat-lying areas in this rugged part of the island. Eastern Tutuila is more sparsely populated than central and western Tutuila. Most of the population is distributed in small villages on the flat-lying terrain at the mouths of valleys. Ground water in eastern Tutuila has been developed from production wells in low-lying areas near the villages of Auto, Fagaitua, Alofau, Alao, Tula, Aoa, Sailele, and Masefau. A non-pumping well in Amouli has been used to monitor water levels.

Aunuu is an island off the southeastern shore of Tutuila (fig. 25). The population of Aunuu resides on a coastal plain on the western end of the island. The area is served by three infiltration galleries, also on the 


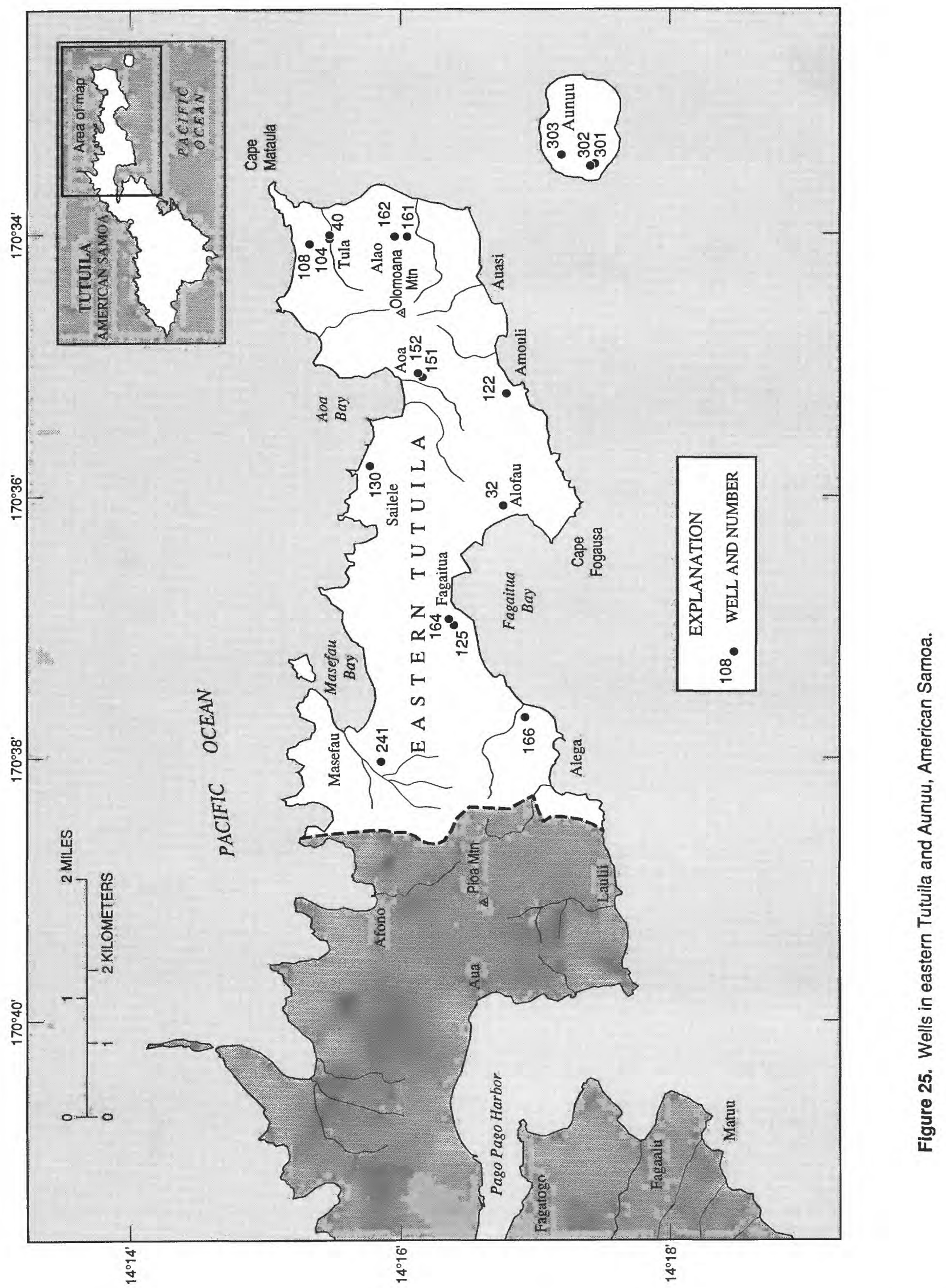




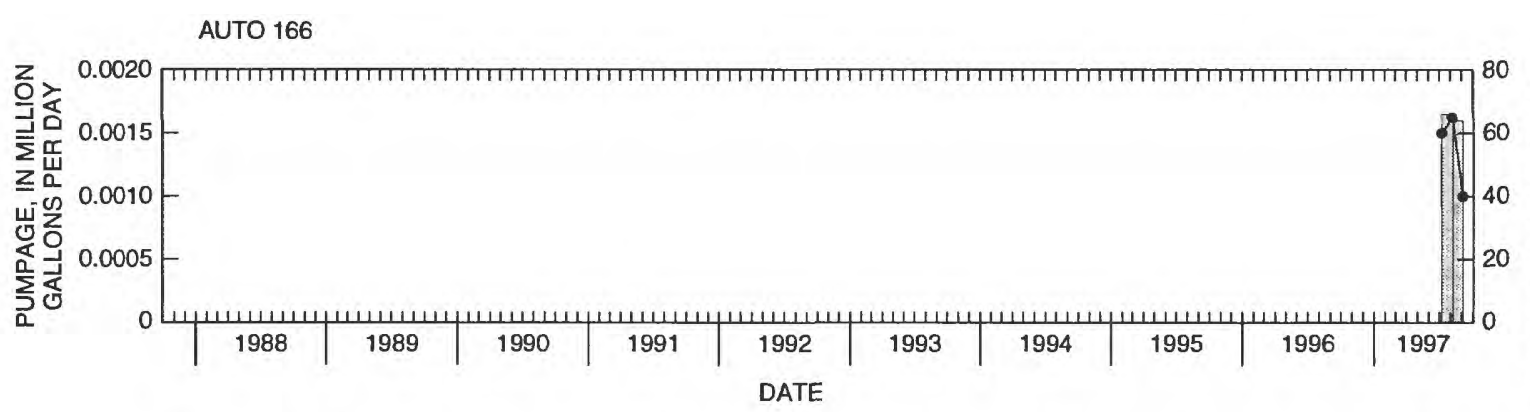

Figure 26. Ground-water pumpage and chloride concentrations in Auto, Tutuila, American Samoa. (Connecting lines provided only as a visual aid and do not imply interpolation between data points.

Data from the American Samoa Power Authority.)

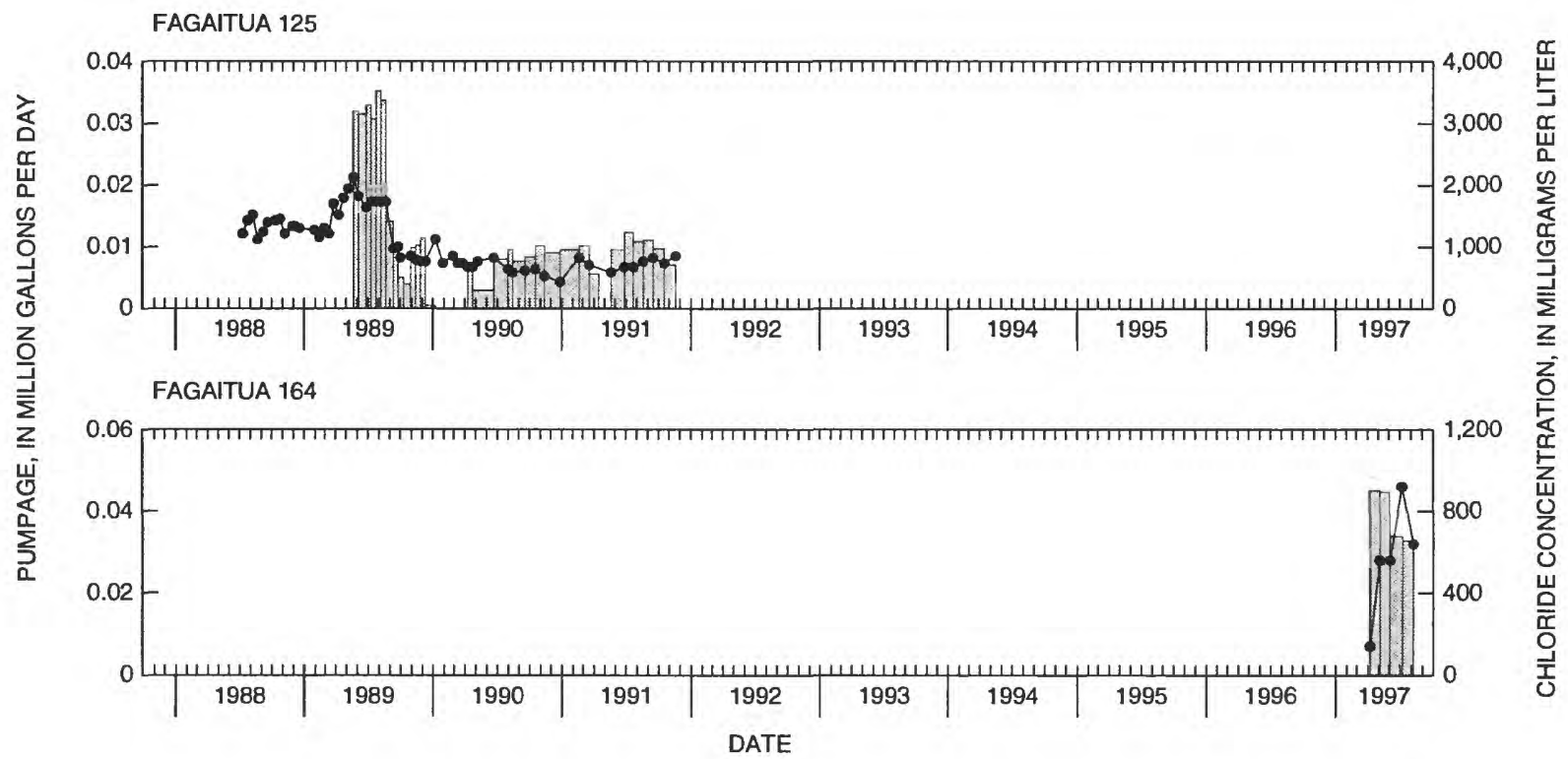

Figure 27. Ground-water pumpage and chloride concentrations in Fagaitua, Tutuila, American Samoa. (Connecting lines provided only as a visual aid and do not imply interpolation between data points. Data from the American Samoa Power Authority.)

coastal plain. Several small dug wells are used to obtain drinking water, but the withdrawal rate from these wells is small compared with the pumpage at the infiltration galleries.

\section{Auto}

Reports of pumpage at new well 166 in Auto on the southern coast of Tutuila (fig. 25) began in July 1997. Pumpage averaged $0.0016 \mathrm{Mgal} / \mathrm{d}$ for the first two full months of reported pumpage (fig. 26). Chloride concentrations ranged from 40 to $65 \mathrm{mg} / \mathrm{L}$.

\section{Fagaitua}

Fagaitua has two production wells. Well 125 (fig. 25) has a pumping record between 1989 and 1991, although the chloride concentration record extends back to 1988 (fig. 27). The water meter was reported to be malfunctioning on April 24, 1989. It is not known how long prior to this date the meter was malfunctioning. At the beginning of the record, chloride concentrations were already higher than $1,000 \mathrm{mg} / \mathrm{L}$. Chloride concentrations rose to nearly $2,000 \mathrm{mg} / \mathrm{L}$ in 1989 during a period when the well was pumping about $0.03 \mathrm{Mgal} / \mathrm{d}$ 


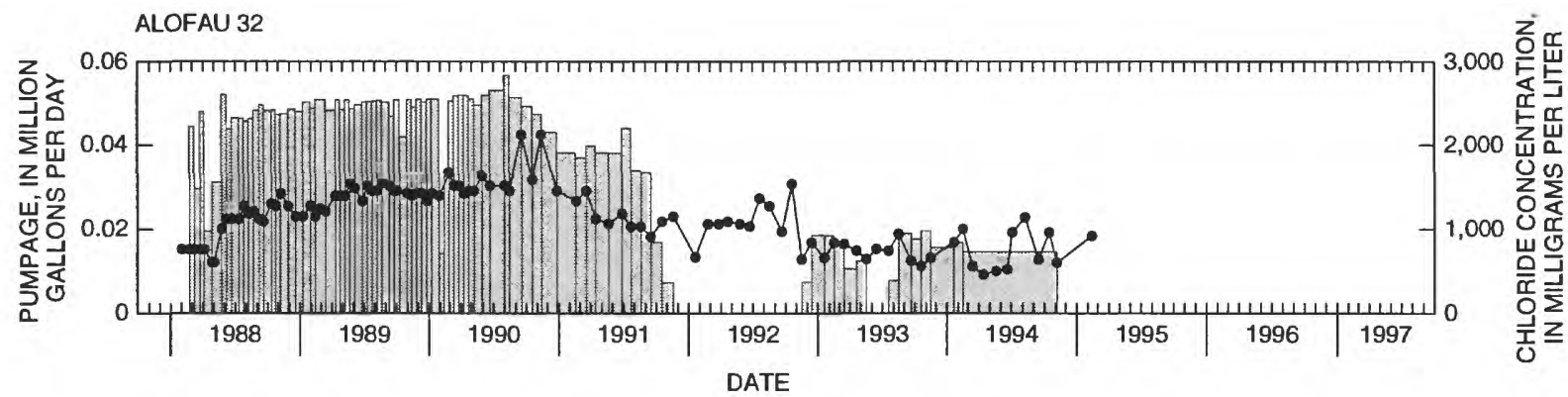

Figure 28. Ground-water pumpage and chloride concentrations in Alofau, Tutuila, American Samoa. (Connecting lines provided only as a visual aid and do not imply interpolation between data points. Data from the American Samoa Power Authority.)

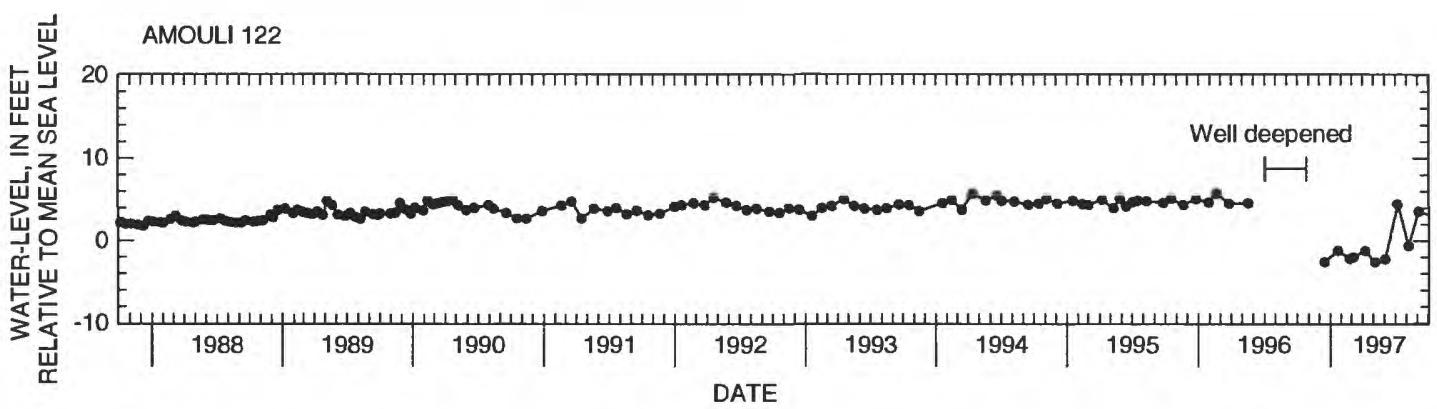

Figure 29. Ground-water levels in Amouli, Tutuila, American Samoa. (Connecting lines provided only as a visual aid and do not imply interpolation between data points. Connecting lines omitted where period between successive data points exceeds 6 months. Data from the American Samoa Power Authority.)

and rainfall was lower than average (fig. 2). Pumpage was reduced in 1989 and stopped for a period in early 1990. Pumping resumed at about $0.01 \mathrm{Mgal} / \mathrm{d}$ in late 1990 and continued to 1991 ; chloride concentrations remained at about $1,000 \mathrm{mg} / \mathrm{L}$ over this period.

Trends during the 12-month period ending September 1997.--A new well (164) began pumping in Fagaitua in April 1997 (fig. 27). Pumpage at the well, for the period April through August 1997, averaged $0.039 \mathrm{Mgal} / \mathrm{d}$. The chloride concentration of the pumped water was $140 \mathrm{mg} / \mathrm{L}$ at the beginning of pumping in April 1997, but rose to $920 \mathrm{mg} / \mathrm{L}$ by July 1997 .

\section{Alofau}

Well 32 in Alofau on the southern coast of Tutuila (fig. 25) pumped at a rate of about $0.05 \mathrm{Mgal} / \mathrm{d}$ in 1988 90 (fig. 28). During this period, chloride concentrations rose from less than $1,000 \mathrm{mg} / \mathrm{L}$ to more than 2,000 $\mathrm{mg} / \mathrm{L}$. Pumpage gradually decreased to zero from mid1990 to the end of 1991, at which time the chloride concentrations gradually decreased to less than $1,000 \mathrm{mg} / \mathrm{L}$. From late 1992 to 1994, pumpage resumed at a rate of 0.01 to $0.02 \mathrm{Mgal} / \mathrm{d}$ and chloride concentrations fluctuated by several hundred milligrams per liter around a median of about $800 \mathrm{mg} / \mathrm{L}$.

\section{Amouli}

Amouli (fig. 25) had no production wells during the 10 -year period shown in figure 28 , but had a well (122) that was used to monitor water levels (fig. 29). Water levels at this well have varied between 3 and $5 \mathrm{ft}$ above mean sea level from 1987 through 1995.

Trends during the 12-month period ending September 1997.--In 1996, well 122 was deepened and pumped during a short test (fig. 29). Water levels measured for the next few months after the deepening and 


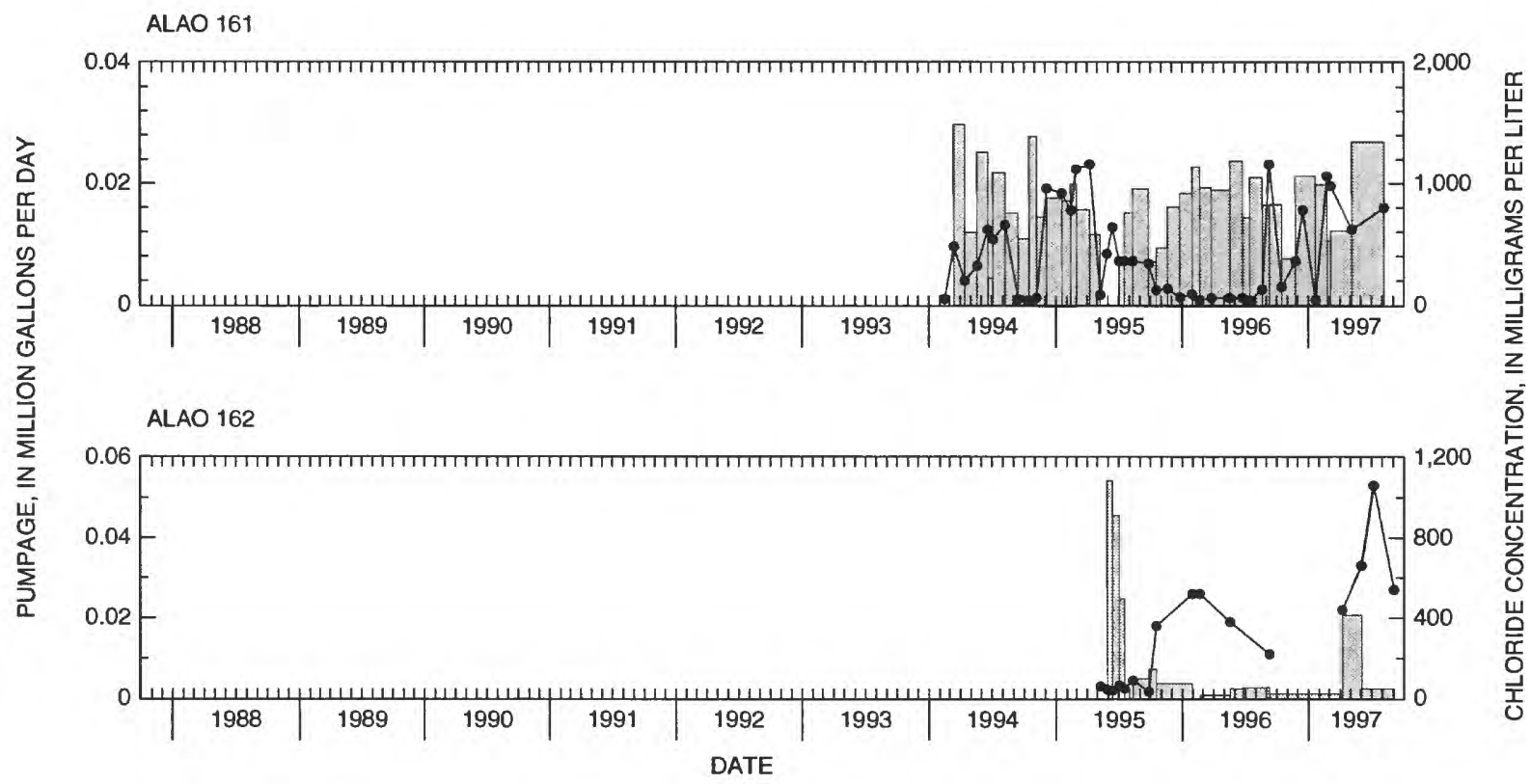

Figure 30. Ground-water pumpage and chloride concentrations in Alao, Tutuila, American Samoa. (Connecting lines provided only as a visual aid and do not imply interpolation between data points. Connecting lines omitted where period between successive data points exceeds 6 months. Data from the American Samoa Power Authority.)

testing were 1 to $3 \mathrm{ft}$ below mean sea level but water levels rose to almost $4 \mathrm{ft}$ above mean sea level by September 1997.

\section{Alao}

Alao has production wells 161 and 162 (fig. 25). Well 161 has pumped an average of $0.018 \mathrm{Mgal} / \mathrm{d}$ since 1994, and chloride concentrations have fluctuated between 40 and $1,160 \mathrm{mg} / \mathrm{L}$ (fig. 30). Pumpage at well 162 began in 1995 at about $0.05 \mathrm{Mgal} / \mathrm{d}$, but was reduced after a few months to intermittent pumpage averaging less than $0.01 \mathrm{Mgal} / \mathrm{d}$. Initial chloride concentrations in the well were below $100 \mathrm{mg} / \mathrm{L}$ but have risen to more than $1,000 \mathrm{mg} / \mathrm{L}$.

Trends during the 12-month period ending September 1997.--During the 12-month period ending September 1997, pumpage at well 161 averaged 0.019 Mgal/d (fig. 30). Chloride concentrations at well 161 rose sharply to $1,160 \mathrm{mg} / \mathrm{L}$ in September 1996 , then fluctuated by hundreds of milligrams per liter over the next 12 months.

During the 12-month period ending September 1997, well 162 continued intermittent pumpage at an average rate of $0.0093 \mathrm{Mgal} / \mathrm{d}$ (fig. 30). In early and mid-1996, chloride concentrations in well 162 had been declining, but began increasing in mid-1996 and reached a high of $1,060 \mathrm{mg} / \mathrm{L}$ (highest on record for the well) in July 1997. Chloride concentrations in this well declined to $540 \mathrm{mg} / \mathrm{L}$ by September 1997.

\section{Tula}

Tula on the eastern end of Tutuila has production wells 40, 104, and 108 (fig. 25). Records for well 40 began in 1991 when pumpage was about $0.04 \mathrm{Mgal} / \mathrm{d}$ (fig. 31). Pumpage was reduced to between 0.01 and $0.02 \mathrm{Mgal} / \mathrm{d}$ by mid-1991. Between 1992 and 1995, the well was pumped intermittently at an average of less than $0.01 \mathrm{Mgal} / \mathrm{d}$. The chloride concentration in well 40 has fluctuated greatly from less than 100 to nearly 2,000 $\mathrm{mg} / \mathrm{L}$. During the period of intermittent pumpage, chloride concentrations remained mostly below $200 \mathrm{mg} / \mathrm{L}$ but twice was measured at more than $900 \mathrm{mg} / \mathrm{L}$. From May 1995 to September 1996, the well was shut down and partially backfilled in an attempt to reduce chloride concentrations in the pumped water. Pumpage resumed at well 40 in September 1996. 


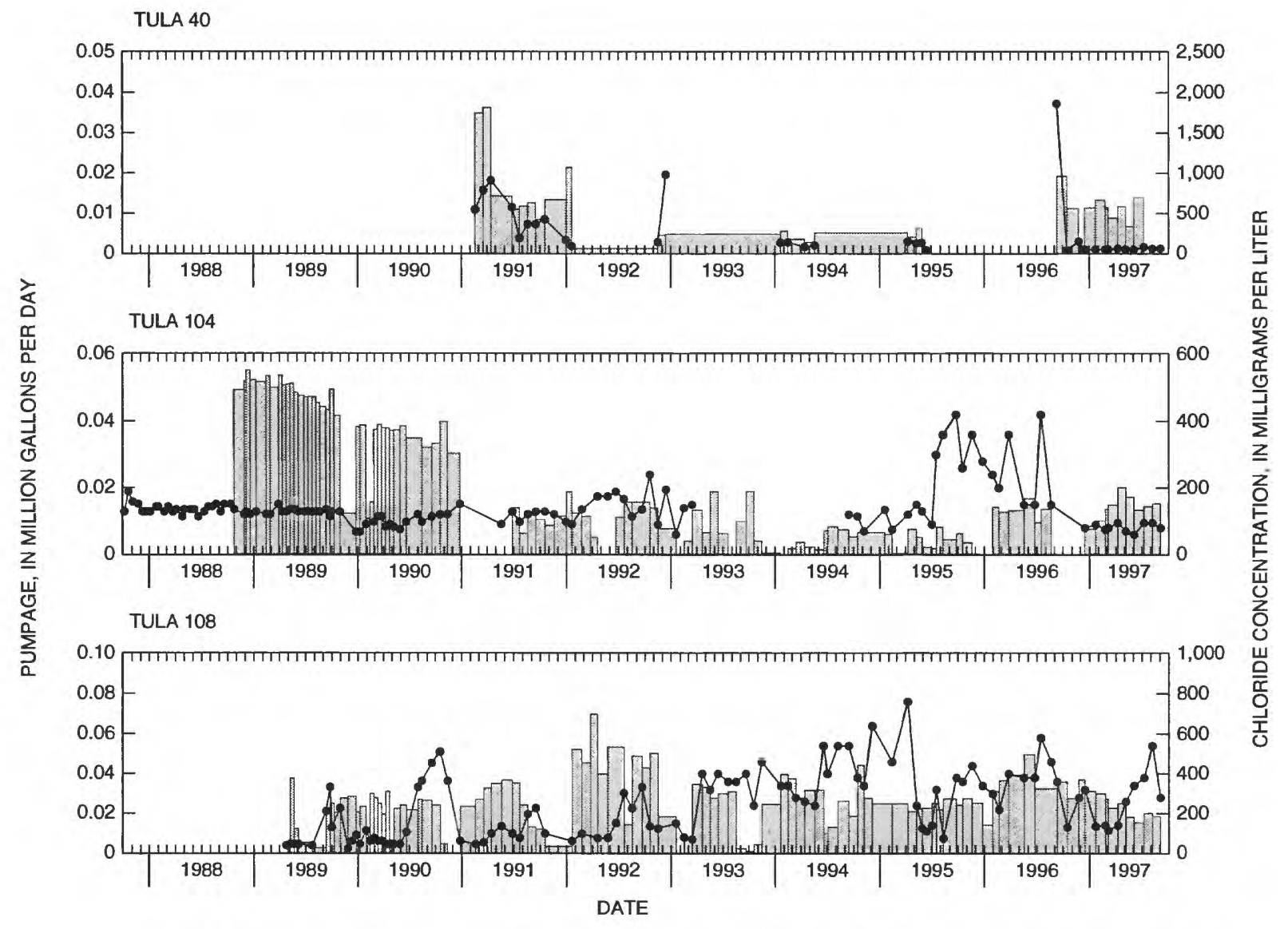

Figure 31. Ground-water pumpage and chloride concentrations in Tula, Tutuila, American Samoa. (Connecting lines are intended as an aid for showing trends and do not imply interpolation between data points. Connecting lines omitted where period between successive data points exceeds 6 months. Data from the American Samoa Power Authority.)

Pumpage records for well 104 began in 1988, when the well produced about $0.05 \mathrm{Mgal} / \mathrm{d}$ (fig. 31 ). Pumpage was gradually reduced to $0.03 \mathrm{Mgal} / \mathrm{d}$ by the end of 1990, and was halted for the first half of 1991. Pumpage resumed in mid-1991 at less than 0.02 $\mathrm{Mgal} / \mathrm{d}$. Chloride concentration in the early part of the record for well 104 remained below $200 \mathrm{mg} / \mathrm{L}$, but rose sharply to as high as $420 \mathrm{mg} / \mathrm{L}$ in September 1995, then fluctuated by hundreds of milligrams per liter through most of 1996.

Pumpage at well 108 varied from 0 to about 0.06 $\mathrm{Mgal} / \mathrm{d}$, with an average of about $0.03 \mathrm{Mgal} / \mathrm{d}$ over the period of record (fig. 31). Chloride concentrations in well 108 in the period from 1989 to early 1990 were mostly below $200 \mathrm{mg} / \mathrm{L}$ with occasional brief rises to as high as $300 \mathrm{mg} / \mathrm{L}$, but after mid-1990, chloride concen- trations rose more frequently and to increasingly higher levels.

Trends during the 12-month period ending September 1997.--Pumpage at well 40 resumed in September 1996 at a rate of about $0.01 \mathrm{Mgal} / \mathrm{d}$ (fig. 31). The first chloride concentration reported since the resumption of pumpage was $1,860 \mathrm{mg} / \mathrm{L}$, but chloride concentrations quickly declined and have remained less than $150 \mathrm{mg} / \mathrm{L}$ since then.

Well 104 was shut off between September and December 1996 (fig. 31). From December 1996 to September 1997, well 104 pumped at an average of 0.014 $\mathrm{Mgal} / \mathrm{d}$. Chloride concentrations at this well during this period were below $100 \mathrm{mg} / \mathrm{L}$, which is lower than all but a few of the chloride concentrations on record for this well. 


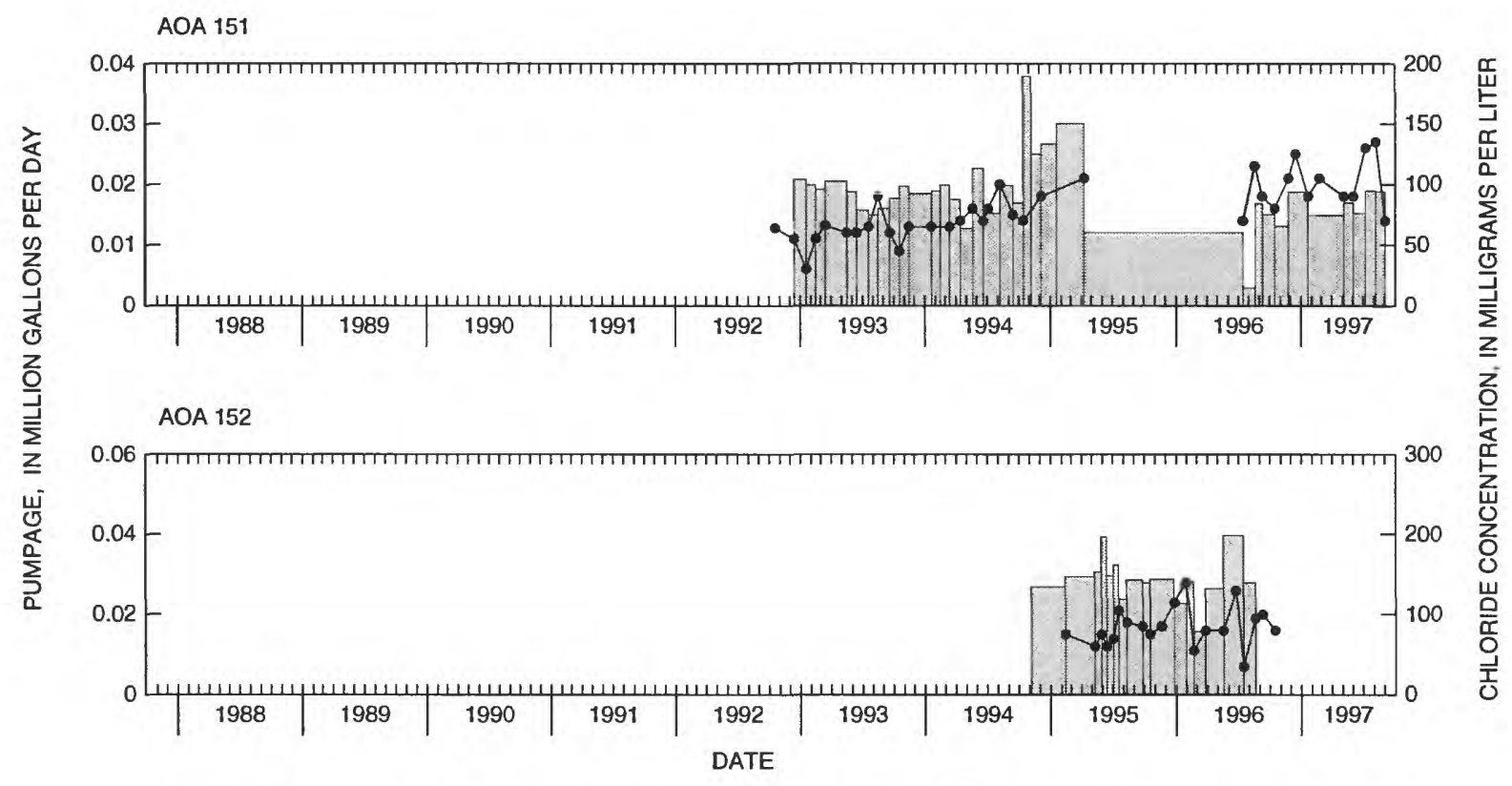

Figure 32. Ground-water pumpage and chloride concentrations in Aoa, Tutuila, American Samoa. (Connecting lines provided only as a visual aid and do not imply interpolation between data points. Connecting lines omitted where period between successive data points exceeds 6 months. Data from the American Samoa Power Authority.)

During the 12-month period ending September 1997, pumpage at well 108 decreased relative to pumpage in early 1996 (fig. 22). During this period, chloride concentrations at well 108 continued a pattern of highly variable chloride concentrations from 115 to $540 \mathrm{mg} / \mathrm{L}$.

\section{Aoa}

Aoa lies in an embayment on the northeastern shore of Tutuila (fig. 25). Two production wells in the village are sited adjacent to a low-lying swampy depression in the back of Aoa Bay. Well 151 has pumped 0.02 to $0.03 \mathrm{Mgal} / \mathrm{d}$ since late 1992 and well $152 \mathrm{pumped}$ between 0.03 to $0.04 \mathrm{Mgal} / \mathrm{d}$ from late 1994 to mid1996 (fig. 32). Chloride concentrations in well 151 were below $200 \mathrm{mg} / \mathrm{L}$ but have risen since the well began pumping. Chloride concentrations in well 152 varied between 55 and $140 \mathrm{mg} / \mathrm{L}$.

Trends during the 12-month period ending September 1997.--Well 151 was pumped at an average rate of about $0.017 \mathrm{Mgal} / \mathrm{d}$ during the 12 -month period ending September 1997 (fig. 32). Chloride concentrations at the well continued on a gradual rising trend that began when the well began pumping in 1992 . No pumpage has been reported for well 152 since July 1996. The last chloride concentrations reported for well 152 (October 1996) was $80 \mathrm{mg} / \mathrm{L}$.

\section{Sailele}

Sailele, on the northeastern coast of Tutuila has one production well (well 130, fig. 25) that has produced 0.01 to $0.03 \mathrm{Mgal} / \mathrm{d}$ since 1987 (fig. 33). Chloride concentrations were about $500 \mathrm{mg} / \mathrm{L}$ through the first 4 years of pumping, then gradually rose beginning in 1991 and reached as high as $1,400 \mathrm{mg} / \mathrm{L}$ in 1993. This rise in chloride concentrations occurred during a period of below-average rainfall between 1987 and 1992 (fig. 2) and after a period of high pumpage in 1992 and 1993. Chloride concentrations since then have fluctuated between 80 and $1,040 \mathrm{mg} / \mathrm{L}$.

Trends during the 12-month period ending September 1997.--During the 12-month period ending September 1997, pumpage at well 130 averaged 0.01 


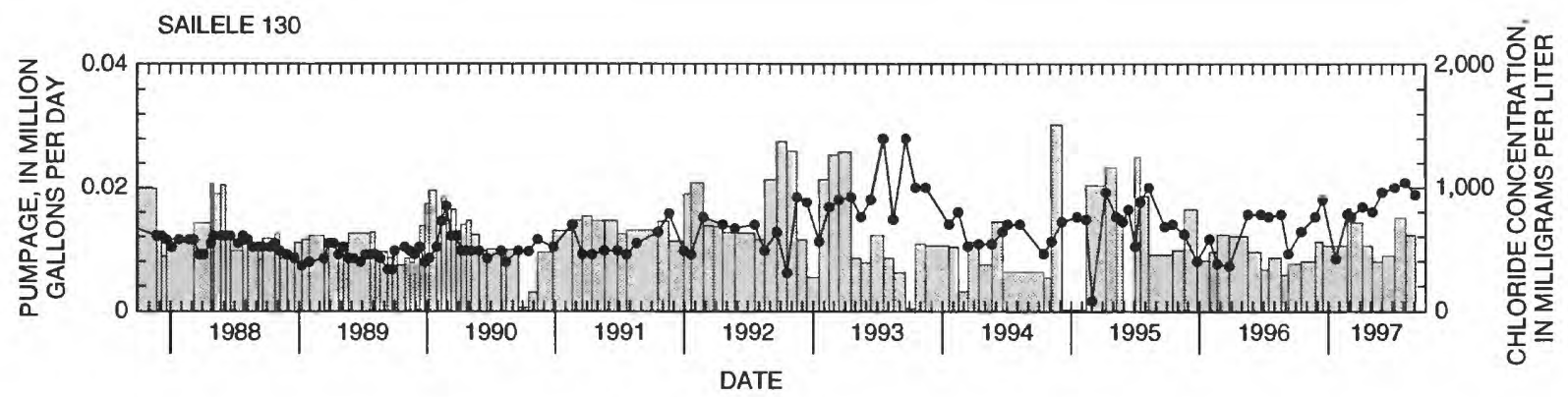

Figure 33. Ground-water pumpage and chloride concentrations in Sailele, Tutuila, American Samoa. (Connecting lines provided only as a visual aid and do not imply interpolation between data points. Data from the American Samoa Power Authority.)

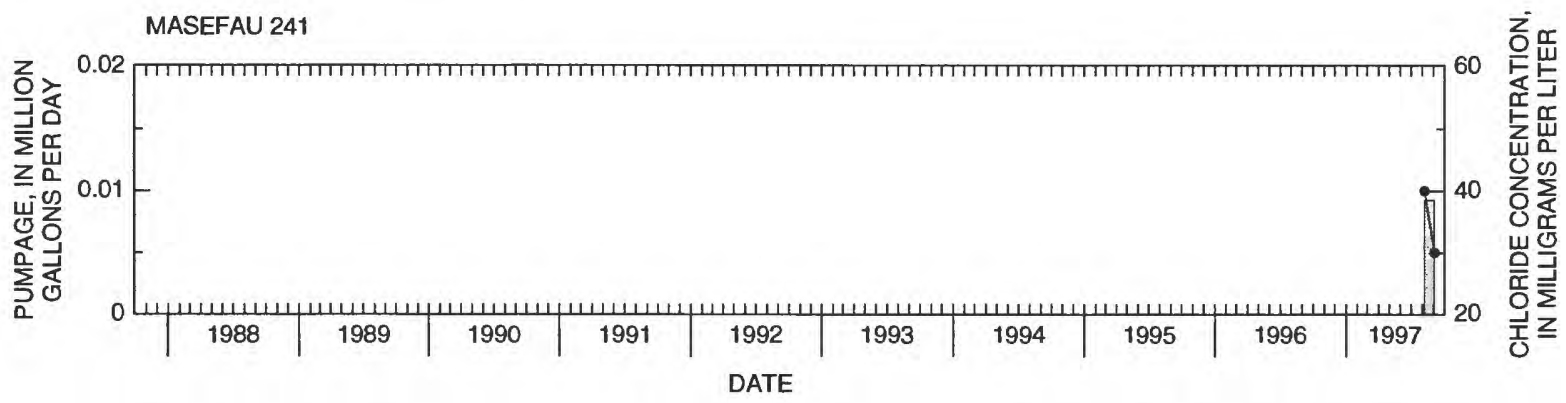

Figure 34. Ground-water pumpage and chloride concentrations in Masefau, Tutuila, American Samoa. (Connecting lines provided only as a visual aid and do not imply interpolation between data points. Data from the American Samoa Power Authority.)

$\mathrm{Mgal} / \mathrm{d}$ (fig. 33). Chloride concentrations were mostly in excess of $500 \mathrm{mg} / \mathrm{L}$ and reached as high as 1,040 $\mathrm{mg} / \mathrm{L}$ (August 1997).

\section{Masefau}

Masefau, located in an embayment on the northern coast of Tutuila, has one new production well (well 241, fig. 25). Pumpage records for well 241 began in August 1997. The well was pumped at about $9,000 \mathrm{gal} / \mathrm{d}$ between August and September 1997 (fig. 34). Water from the well had a chloride concentration of $40 \mathrm{mg} / \mathrm{L}$ in August 1997, and $30 \mathrm{mg} / \mathrm{L}$ in September 1997.

\section{Aunuu}

Ground-water production on Aunuu (fig. 25) comes from three infiltration galleries (wells 301, 302, and 303) that began pumping in 1992 at about 0.01 to $0.05 \mathrm{Mgal} / \mathrm{d}$ each (fig. 35). Pumpage at well 301 shows an increasing trend since pumping began. Pumpage at well 302 showed an increasing trend between 1992 and early 1994, but decreased in late 1994. Pumpage at well 303 has been intermittent over the period of record. Chloride concentrations in all wells were initially low but rose quickly as pumping continued. Chloride concentrations in wells 301 and 302 were mostly in excess of $500 \mathrm{mg} / \mathrm{L}$ and have exceeded $1,000 \mathrm{mg} / \mathrm{L}$ more than once over the period of record. Chloride concentrations in well 303 have also exceeded $1,000 \mathrm{mg} / \mathrm{L}$ several times, but were mostly below $500 \mathrm{mg} / \mathrm{L}$.

Trends during the 12-month period ending September 1997.--During the 12-month period ending September 1997, pumpage at well 301 averaged 0.04 $\mathrm{Mgal} / \mathrm{d}$, which is about twice the average pumpage in previous years since 1992 (fig. 35). Well 302 continued 


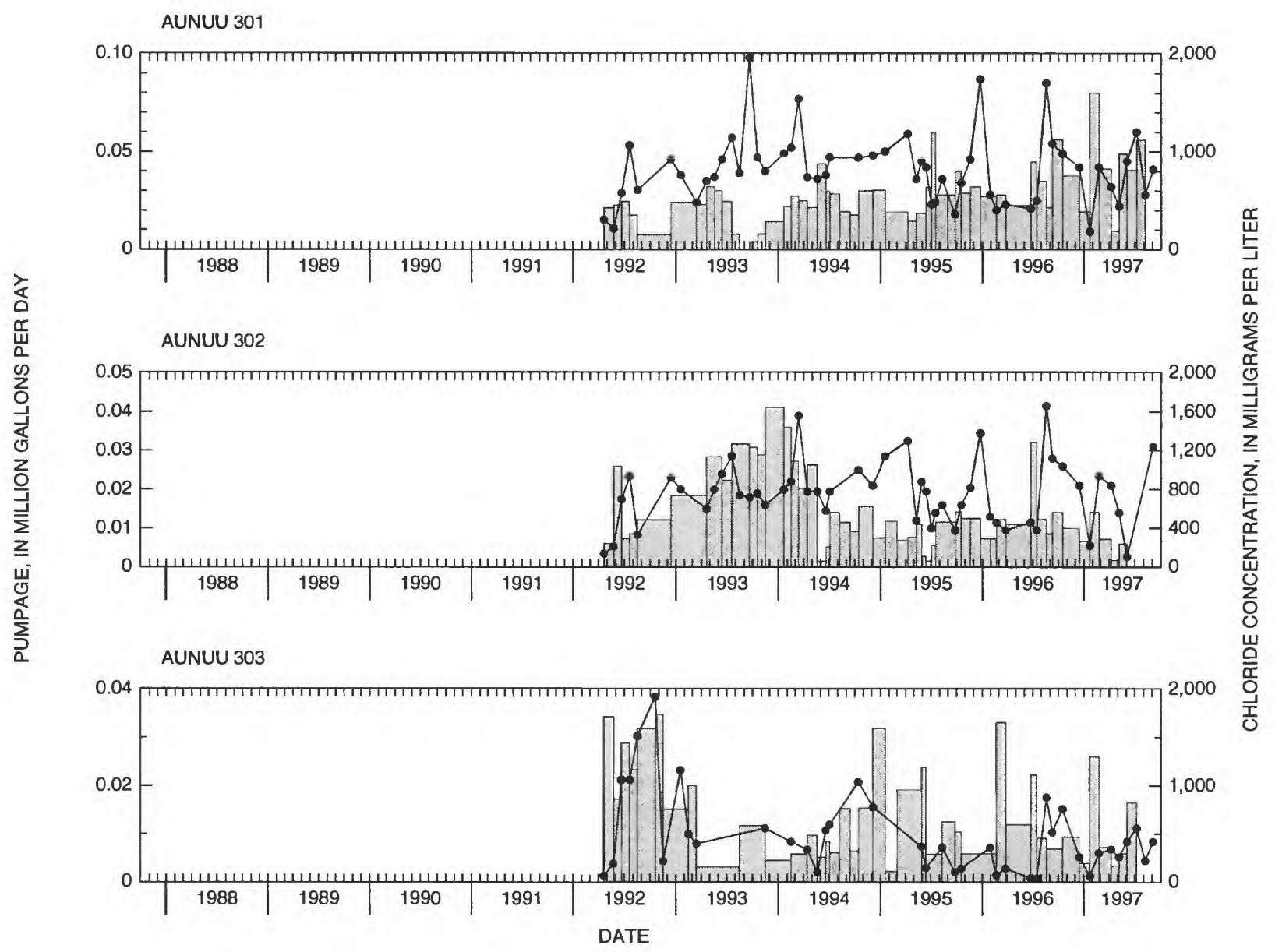

Figure 35. Ground-water pumpage and chloride concentrations on Aunuu, American Samoa. (Connecting lines provided only as a visual aid and do not imply interpolation between data points. Data from the American Samoa Power Authority.)

to pump at an average of $0.008 \mathrm{Mgal} / \mathrm{d}$, which is about the same rate that had persisted at this wells since pumpage was reduced in 1994. Well 303 was pumped intermittently, as it had been since 1992. No meter reading was reported for well 301 in September 1997; for well 302 in July, August, and September 1997; and for well 303 in August and September 1997.

Chloride concentrations in the three Aunuu wells were relatively high in October 1996 but decreased sharply by January 1997 (fig. 35). Between January and September 1997, chloride concentrations varied between 180 and $1,200 \mathrm{mg} / \mathrm{L}$ at well 301 , between 104 and $1,240 \mathrm{mg} / \mathrm{L}$ at well 302 , and between 60 and 560 $\mathrm{mg} / \mathrm{L}$ at well 303.

\section{SUMMARY}

Ground-water and rainfall data summarized for the period October 1987 through September 1997 from Tutuila and Aunuu, American Samoa, include pumpage and chloride concentrations from 53 production wells on Tutuila (including new wells 143 in Fagasa, 164 in Fagaitua, 165 in Pago Pago, 166 in Auto, and 241 in Masefau), 3 production wells on Aunuu, water-level measurements from 16 wells on Tutuila, and rainfall data from 2 gages on Tutuila.

Mean annual rainfall at the gage in Afono near Pioa Mountain was 164 inches, and 210 inches at the rain gage in Aasufou during the period October 1987 through September 1997. Rainfall in the 12-month 
period from October 1996 through September 1997 totaled 210 inches at the Afono gage, and 234 inches at the Aasufou gage.

Most wells in the Tafuna-Leone Plain (Tafunafou, Malaeimi-Mesepa, Malaeloa-Leone, and Iliili) have been pumped at rates from 0.2 to $0.5 \mathrm{Mgal} / \mathrm{d}$ and have had chloride concentrations usually less than $500 \mathrm{mg} / \mathrm{L}$. The high production and low chloride concentrations continued through the 12-month period ending September 1997, when combined pumpage from the TafunaLeone Plain was $6.3 \mathrm{Mgal} / \mathrm{d}$, with $1.6 \mathrm{Mgal} / \mathrm{d}$ from the wells in Tafunafou, $1.6 \mathrm{Mgal} / \mathrm{d}$ from wells in the Malaeimi-Mesepa area, $2.0 \mathrm{Mgal} / \mathrm{d}$ from the Malaeloa-Leone area, and $1.1 \mathrm{Mgal} / \mathrm{d}$ from Iliili, and chloride concentrations in most wells remained below $200 \mathrm{mg} / \mathrm{L}$. In the 12-month period ending September 1997, measured water levels in Tafunafou and Iliili remained at about the same elevation relative to mean sea level as in the previous 10 years, but water levels in Malaeimi have declined overall since mid-1996.

In contrast most wells in central and eastern Tutuila, as well as in the uplands of western Tutuila, have been pumped at rates less than $0.1 \mathrm{Mgal} / \mathrm{d}$. Wells in Fagatogo, Pago Pago, and Aua were exceptions; some wells in these areas have been pumped at rates of more than $0.4 \mathrm{Mgal} / \mathrm{d}$. Some of the wells in central and eastern Tutuila frequently had chloride concentrations in excess of $500 \mathrm{mg} / \mathrm{L}$. In the 12-month period ending in September 1997, chloride concentrations in both production wells in Aua rose to the highest levels on record for those wells. In the 12-month period ending September 1997, measured water levels in Pago Pago remained at about the same elevation above mean sea level as in the previous 3 years, measured water levels in Aua remained below mean sea level as in the previous 2 years, and measured water levels in Fagaalu continued the trend established in early 1996 when water levels dropped relative to the previous 4 years. Water levels measured in Laulii in the 12-month period ending September 1997 included the lowest levels measured in the last 10 years.

The three production wells on Aunuu have been pumped at various rates less than $0.1 \mathrm{Mgal} / \mathrm{d}$. Chloride concentrations in these wells have varied greatly, but remained mostly above $500 \mathrm{mg} / \mathrm{L}$ and often exceeded $1,000 \mathrm{mg} / \mathrm{L}$. In the 12-month period ending in September 1997, pumpage at well 301 continued the increasing trend that began in 1992, well 302 pumped at about the same rate that had persisted since 1994, and well 303 was pumped intermittently, as it had been since 1992. In the 12-month period ending September 1997, chloride concentrations in the three Aunuu wells varied between 60 and $1,240 \mathrm{mg} / \mathrm{L}$.

\section{REFERENCES CITED}

Bentley, C.B., 1975, Ground-water resources of American Samoa with emphasis on the Tafuna-Leone Plain, Tutuila Island: U.S. Geological Survey Water-Resources Investigations Report 29-75, 32 p.

Davis, D.A., 1963, Ground-water reconnaissance of American Samoa: U.S. Geological Survey Water-Supply Paper 1608-C, $21 \mathrm{p}$.

Izuka, S.K., 1996, Summary of ground-water and rainfall data for Tutuila and Aunuu Islands, American Samoa, for July 1984 through September 1995: U.S. Geological Survey Water-Resources Open-File Report 96-116, 44 p.

Izuka, S.K., 1997, Summary of ground-water data for Tutuila and Aunuu, American Samoa, for July 1985 through September 1996: U.S. Geological Survey WaterResources Open-File Report 97-654, 44 p.

Macdonald, G.A., 1944, Petrography of the Samoan Islands: Geological Society of America Bulletin, v. 56, p. 1,3331,362 .

Macdonald, G.A., 1968, A contribution to the petrology of Tutuila, American Samoa: Geologischen Rundschau, v. 57 , no. 3 , p. $821-837$.

Stearns, H.T., 1944, Geology of the Samoan Islands: Geological Society of America Bulletin, v. 55, p. 1,279-1,332.

U.S. Geological Survey, 1989, Topographic map of Tutuila Island, American Samoa: 1:24,000 scale.

\section{APPENDIX}

\section{Data Processing}

Pumpage and chloride-concentration data of all pumping wells, water levels of selected nonpumping and pumping wells, and rainfall data were collected by ASPA and sent to the USGS, where the data were processed as described below.

Daily rainfall recorded at the rain gages were summed over each month and the monthly totals were divided by the number of days in each month to obtain the monthly mean rainfall, in inches per day. The 3 - 
month backward-looking moving average was computed by averaging a given month's rainfall with the rainfall of the 2 months immediately preceding it. The mean monthly rainfall for a given month, for example October, is the arithmetic average of the mean monthly rainfall for all Octobers in the 10 -year period of this report.

Chloride concentrations were determined by a field titration kit. A quality-control check was conducted in 1984 and 1985 in which splits of 123 groundwater samples from Samoa were analyzed using the field titration kits and laboratory titration. Comparison of the results indicated that for most of the samples, the field measurement was lower than the laboratory measurement. In four samples, the field measurement was more than $100 \mathrm{mg} / \mathrm{L}$ less than the laboratory titration. The cause of the discrepancy was not determined. More detailed records of the field titration have been kept since the 1984-85 check, but there have been no subsequent quality-control checks. Although a few measurements showed large discrepancies, 87 percent of the field determinations were within $50 \mathrm{mg} / \mathrm{L}$ of the laboratory measurement. For the purposes of this report, the accuracy of the chloride-concentration data is sufficient to track general trends in the quality of well water.

Average pumpage rates in this report were calculated directly from meter readings supplied by ASPA. Pumpage over an interval was computed by taking the difference between successive readings and dividing by the number of days between the readings. This allowed the pumping rates of intervals of different duration to be compared. Occasional errors in the meter readings (identified because they yielded negative pumpages or pumpages that were too high to have been obtained with the capacity of the pump in the well) were corrected by first classifying the type and possible cause of the error and making appropriate corrections (Izuka, 1996). In a few cases in which the source of the error could not be determined, the meter reading was eliminated and the next correct reading was used in the calculation. In such cases, the bar on the graph appears wider because it represents an average pumpage over a longer period. A wide bar does not necessarily indicate steady pumpage; steady pumpage is indicated by numerous bars of the same height.

If pumpage at a well was halted for a month or more and the date of the shutdown, the last reading after the shutdown, and the date of the start-up are unknown, the difference between the last meter reading prior to the shutdown and the first meter reading after resumption was divided by the number of days between the two readings. This results in a bar that is relatively low (because no water was pumped during part of the interval) and wide (because there was a long interval between meter readings). Therefore, a wide bar that is much lower than the adjacent bars probably indicates that the well was shut down during some part of the interval spanned by the bar.

This is the third in a series of ground-water data reports for Tutuila and American Samoa. Errors and omissions discovered since the publication of the last report (Izuka, 1997) have been corrected in this report. 